\title{
3
}

\section{The Dark Chapter}

But what happened between 1943 and 1946 that required him to turn the page and start a new chapter in his life? There must have been fateful events that were decisive in setting the course for the rest of his life. 'If I hadn't experienced it myself, I wouldn't have believed it.' That was how Rolf rounded off the summary of his life when he was interviewed at the age of 91. He had spoken at length about curiosity and research, about aiming for apparently impossible goals, about holding the banner high in the face of opposition and doubt. He had said a little about unpredictability and chance both in research and in the course of his life, and about being at the right place at the right time-or not. ${ }^{1}$

He may have been surprised at the strange turns a life could take, especially during these three war years, but he never made a drama of it, either publically or privately. That was not in his script as an engineer. Nor was complaint part of his role. While this strange phase was playing out with its questions and rumours, his energy was fully taken up just in living through it. Later, he found a way to live with it. The dark chapter was the tipping point in his life, as amazing as it was frightful. It was when everything that should not happen, everything that nobody thought could happen, did happen. It was beyond what family, friends, neighbours or colleagues could imagine. At the same time it was one of the most creative periods of his life, when his absorbing scientific dream came true. Against the very saddest, weirdest, bleakest backdrop, this was and remained the dark chapter. The odd, painful, revenant scene. 
Spring and summer 1943 were sufficiently dramatic times, even without his part in the action. The war had come to a phase when the Germans were beginning to be desperate. Hitler needed something to impress both his own side and the enemy. Nazi Germany was working to develop an atomic weapon. Britain, the USA and France were doing the same. The question was who would achieve this first.

Research into splitting the atom had been under way on both sides of the Atlantic when the war started in Europe. Atomic research now became part of the war effort. The British and Canadian atomic research programmes were joined together with the American programmes into a super-secret project code-named 'Manhattan.' Lawrence with his bigger and bigger cyclotrons was a key person in this. Working with him was the American expert in theoretical physics, Robert Oppenheimer, who later came to be described as 'the father of the atom bomb.' A dedicated laboratory was set up in New Mexico to build the bomb, with Oppenheimer as the lead scientist. The theories were in place, but it was a race against time. Would they manage to build an atomic weapon in time for it to be used in the war?

The Allied intelligence services knew that the Germans had a uranium project, and in the summer of 1943 they reckoned that the Germans would not manage to build an atomic weapon before the war was over. Few people knew what was really happening in German atomic research. Some thought it was mostly bluff and propaganda. What they knew for certain was that atomic research in Germany was under the control of the military. German science was at a high level, and the Allies assumed that the Nazis would use the new knowledge about atom-splitting to create atomic weapons.

On the other hand, the politicisation and Nazi control of the academic milieu had led many physicists and mathematicians to leave Germany as early as 1933, the year after Rolf moved home to Norway. Many others had been called up into regular war service. Moreover, many of the German scientists were Jews who had been driven into exile. So the amount of available expertise had been diminished. Nevertheless, the Allies worked intensively to get ahead of the Germans. And they knew about Rolf's work in Germany for the Luftwaffe.

\section{The Visitation at Work}

The competition to be first to develop the new technology that could decide the end of the war grew more and more acute. Nobody on the other side must know anything. Everybody was watching everybody else. The strongest 
weapon of all was fear. Either side could use this, whatever their position in the arms race, and it was used for all it was worth, especially by the Nazis.

This was the underlying situation as Rolf, father of three children, cycled through Oslo each day to and from his work planning modern power supplies for Norway. At home in the evenings, he continued to develop further the ideas he had proposed in his doctoral thesis.

Then one day in spring 1943 his life changed. Some Germans visited him at the office. Surprisingly, it is difficult to find out exactly when this happened. Rolf never tried afterwards to set a definite date to the event. Maybe he didn't want to? It is unthinkable that such a realist and systematic researcher didn't know the date it happened. However, he has several times described the episode that took place in the back yard at NEBB while he was fixing something or other on his bicycle. Apparently he was just about to leave for home when they turned up. The timing and location of the German visitation had been carefully planned. Suddenly, there they were behind him; uniformed SS officers from the German air force, the Luftwaffe; like a scene in a war film. ${ }^{2}$

Nor did Rolf say exactly how many there were, or when it was; just that it was good weather and that there were 'two or three' of them. While he is unclear about apparently incidental information, at the same time he is clear and precise about other things. Many years later, information would emerge that spreads light on this paradox, but as with so much else to do with Rolf's life at this time, some details still remain shrouded in mist.

The Germans asked him very politely if he would accompany them to the Grand Hotel, as there was something they wanted to speak to him about. They said it was to do with something that could be very important for his brother. Viggo had been a prisoner in Germany for two years, and the family had learned that his condition was steadily deteriorating. He had recently been moved to a new prison camp, a little further north. The family was worried about how the combination of forced labour, under-nutrition and disease was affecting him.

What could the Germans have wanted from Rolf? When there is war, your country is occupied and emissaries from the enemy want you to go with them, you really don't have much choice-irrespective of how politely they conduct their business and irrespective of whether they are two or three in number. Rolf gains a little extra thinking time by saying that he needs to fix his bicycle before he can go with them. Yes of course, he is allowed to do that. They appear to be on an important errand, and they want to play ball with him. To be stopped by Germans was not in itself very unusual at that time. So maybe he wasn't so surprised? It is also difficult to judge how 
surprised he was that they had sought out him in particular. He has never said anything clearly about that.

\section{Why Rolf?}

The war is now in its fourth year. For Norwegians, the obtrusive behaviour of the occupying powers has become a part of everyday life. People have a deep fear that a German will suddenly appear at the door, probably in the middle of the night or early in the morning. Everybody knows someone who has been taken that way. But what do they want with Rolf? Why now? Has he been arrested? What has he done? It must be something to do with his work; he has always had a lot of dealings with Germany. And his granny is German.

Rolf agrees to follow them to the Grand Hotel. There, he gets to know more. They obviously want his help towards some objective, and they obviously have something to give in exchange. We really don't know what Rolf's thoughts were in the Grand Hotel on Karl Johans Gate. He has spoken about the episode in several interviews, but has always stuck to the standard version, a sober and carefully thought out account of what happened. He has never really said what he thought or felt.

We can only speculate. We can wonder if the thought crossed his mind that they wanted to recruit him as a spy. He was a good candidate for that; he spoke fluent German, had lived in Germany for ten years and had a wide network of contacts.

The officers had taken him to a neutral location, but they still wouldn't tell him exactly what they wanted of him. It is difficult to say to what extent he thought at the time that it might have something to do with his brother. He may have thought that they were just using that idea as bait. He may have reasoned that Viggo's situation was now so bad that if there was the faintest ray of hope that he could help him in any way, anything was worth trying-even contact with the Germans. There were other possibilities, however.

The talks continued the next day. The Germans appeared to be experts on X-rays, and they had prepared well. He realised that they knew everything about his education; that he had studied in Karlsruhe and had done his doctorate in Aachen. They knew the contents of his thesis. They understood that he had worked in Germany but had moved back to Norway. What's more, they knew that he had recently published an article in the March number of Archiv für Elektrotechnik, the journal that had published his 
doctoral thesis 15 years before. The article discussed both his own and the Americans' work on radiation and included new ideas about betatrons of different sizes.

It would be no surprise that Rolf now discerned the plan. The Germans wanted him for purely scientific reasons. Thinking about his latest published paper, he realises how well-informed the Germans are. Few people understand the significance of what he has written. These officers must have contacts at the very peak of the European physics community. It is not unusual for the occupying powers to employ flattery in pursuit of their objectives. Flattery is but one among many techniques considered legitimate, but this is more than flattery. These people know what they are talking about. They are talking about his own big research ideas.

They would like to take him to a third location, to Berlin, to continue the conversation. Everything is being conducted using best espionage technique. He is still uncertain. They suggest that they might be able to help his brother. They even imply that Viggo might be released. They don't have full authority themselves, but they could have a word in the right ears. 'That was decisive for me, and I agreed to continue the conversations in Berlin,' he said later.

Perhaps they would take up his brother's case, perhaps not. Anyway, he went with them to Berlin, a city he knew well after spending almost four years with AEG. A student friend of his lived there, Ernst Sommerfeld who was now a respected patent consultant and who had helped him with several patent applications in recent years.

\section{A Few Days Later}

He should go to Berlin now. Immediately. By air. The immediacy is not unexpected, but to go by plane is more unusual. By air? Immediately? It must be important. A day or two after the first contact, he is already on his way to Germany. All planned with Teutonic efficiency.

In Berlin they come to the point, or near to it. They want a betatron built. The work is to take place in Hamburg. The authorities have assigned priority to the project. There is a possibility that they might want more and perhaps even bigger machines created later. They consider Rolf to be the leading expert in this technology and they want him to be lead scientist for the whole project. And-by the way-if he will collaborate with their plans they will do what they can do to improve his brother's prison conditions, or possibly even have him released. So they said. 
When we hear tell of such an episode nowadays we may think, as many did at the time: It's war; people are being picked out, arrested, ordered to do this or not do that; we are under enemy rule. When several high-ranking, uniformed enemy representatives come on a special mission to 'negotiate,' the alarm bells ring, the sirens wail, the horns resonate, all the warning beacons flare. You know where you stand. Is that how Rolf reacted?

The Germans explained to Rolf what they already knew about the topic. They knew for example about Donald Kerst's article from 1941, the one Rolf had heard about during Professor Roald Tangen's lecture in Oslo. They knew that in the USA, Kerst had succeeded in building a working betatron with an energy level of $2.3 \mathrm{MeV}$. They had read about Rolf, who had developed the theory that the Americans had worked out in practice. They knew that Rolf had worked for many years developing equipment for the Norwegian power industry and that he had taken up his youthful idea again and started following the research developments especially closely. They also knew that he had changed his job to work in a more stimulating environment. We are talking here of surveillance, not to mention industrial espionage and commercial secrets.

\section{The Industry Speeds up}

Over the previous few years Rolf had been in contact from time to time with the Brown Boveri parent company in Switzerland. He had suggested that they should begin to build radiation transformers, and in one of the letters the Brown Boveri management remind him that he mustn't forget to patent his ideas in Germany-and in the USA and England as soon as possible after the war. They offered to help him with this, because industrialists on both sides of the Atlantic were now interested in betatrons. The Siemens factory had already started building a small, $6 \mathrm{MeV}$ betatron. The X-ray specialist Konrad Gund had been selected to lead this project, which was based on the ideas and designs of Max Steenbeck, whom Rolf knew from his time in Berlin after his student days.

The German authorities were obviously following research developments carefully. They needed to be ahead of the competition, and there were abundant fantasies about what they had in mind. Through his contacts, Rolf had been carefully following the race that was under way both in industry and in research. So why should he be surprised that the Germans tried to persuade him to build betatrons for them? What's more, to build a betatron had been his youthful dream. An American had recently succeeded. Now it was Rolf's 
turn to build an even bigger and better one. After all, Kerst had built on the theoretical foundations Rolf had laid. And even though the job in NEBB gave him better opportunities than his previous job, he did not have access to the resources needed for an undertaking on this scale. Neither the money nor the equipment. Norway didn't have these. Certainly not now. Here facing him was his opportunity. Laboratory, staff, money; you are the boss. Do what you want. Just build a betatron, $15 \mathrm{MeV}$. And quickly.

This was the opportunity to apply his latest ideas about a betatron with high enough energy to be used in cancer treatment. He had no special knowledge of radiobiology or radiotherapy, but as a physicist he understood how radiation can penetrate into a cancerous tumour. He could foresee that high energy rays could deliver bigger doses of radiation into the tumour itself and smaller doses into the overlying healthy tissue, thereby reducing the damaging side-effects. Using high energy, radiotherapy could be more effective, especially in the treatment of deep-seated tumours. The higher the energy, the greater the effect. He probably thought that an energy level more than $15 \mathrm{MeV}$ would be even better, but if the Germans wanted a $15 \mathrm{MeV}$ machine, that's fine. Let them have it. It's a start, anyway. A good enough challenge, a victory in sight. And-if he was successful-a machine that could help cancer patients. Was that his motivation?

\section{Contacts}

Rolf had professional contacts with whom he had exchanged letters the previous winter. Among these was a professor in Berlin who sent him long letters full of formulae and always ending with 'Heil Hitler!' Throughout the spring, Rolf had been working on a follow-up article for the journal. The editorial staff registered it as 'received' on Monday 12th July. In the article, Rolf presents new details about how one could build not just a $15 \mathrm{MeV}$ but a $200 \mathrm{MeV}$ betatron. ${ }^{4}$ The only snag was that the article was never printed. It was typeset and Rolf checked the proof-reading, but it mysteriously disappeared before going to press. ${ }^{5}$ Censorship? Industrial espionage? Accident? Who knows what in a time of war? Maybe he contacted the editors to remind them or to ask what had happened. That would not have been odd, but most of us would say that it was unusual for a Norwegian to send articles to a German technical journal during the war, however scientific the content. He later learned that the article had been stamped 'Geheim' ('Secret') and so could not be published. For selected eyes only. So even 
though the article had not been published, somebody in authority knew of its content.

The editorial office was in Berlin. In theory he could have taken the article with him and handed it in personally, but in the prevailing circumstances it is unlikely that he could have visited a publishing house. Was the editor playing a part in a wider game? These are the types of speculation that arise in the absence of hard facts.

Did the visit to Berlin make it possible for Rolf to be present in person when he registered his first German patent on 15th July? That is even more unlikely. In connection with the patent registration, he had had legal advice from his friend Sommerfeld. Did he visit Sommerfeld? We don't know how much freedom he had. If the Germans knew that he was seeking to make progress both with the article and with the patent registration, was it a particularly suitable time to lure him to Berlin? We may never find answers to this sort of question. However, it can be useful to pose these questions and consider the information we do have, because some of it seems almost too positive. Some facts are completely missing, though Rolf often informs us about things that seem less important. Though striking, this contrast is not necessarily intentional.

\section{German Contacts}

The visit to Germany may also have given Rolf an opportunity to meet another German contact who is particularly interesting in this context, namely Director Schwartz whom Rolf had got to know when he visited NEBB in Oslo several times. We know that Rolf at some time had floated the idea to Schwartz of appealing for a reprieve for his brother. Schwartz was employed in the German government agency responsible for the extension of Norwegian hydro power, and Rolf knew that he had contacts with Engineer Fritz Todt, who was the German arms minister at the beginning of the war. Rolf asked Schwartz for help to direct the appeal into the correct channels so that it would reach someone with decision-making authority. Scwartz replied that yes, he could help, but that the appeal would obviously be much stronger if Rolf could say that he had done something such as publishing an article with a pro-German attitude or donating a suitable sum to a pro-German organisation. Schwartz said that such things would be taken into account when the appeal was being considered. ${ }^{6}$

But do we know whether this Director Schwartz was part of the whole structure? Was he connected with the officers who came to Norway to 
persuade Rolf? Was he really Rolf's friend and confidant? What did the German authorities know about his contact with Rolf? Were they directing the play? There is little to suggest that, but Rolf followed the script. He already had an article he could refer them to. It could be found in Teknisk Ukeblad ('Technical Weekly') the previous year, no. 15, 16th April 1942, in the form of a report of the visit he had made to Germany the previous autumn as part of a Norwegian delegation to study the development of power supplies. A Director Schwarz crops up here, as tour leader and with his name spelled without a 't.' Probably the same person. The article was headed: 'Technical impressions from the Norwegian engineers' study tour in Germany 10-23 September 1941. By Dr. Eng. Rolf Widerøe.' The introduction left no doubt about who had extended the invitation:

On the initiative of Reichskommissar Terboven and Reichsminister Dr. Eng. Todt, General Inspector for Water and Energy, Arbeitsgemeinschaft für den Elektrizitätsausbau Norwegens this summer invited several Norwegian hydropower and electrical engineers to a study tour in Germany to see and learn about the utilisation of German energy sources.

Rolf wrote glowingly about the people who had arranged the tour and who had 'a significant part of the credit for the fact that the power system was all so complete and effective.' He relates that 18 Norwegian engineers took part and that the tour leaders were Director Schwarz and Dr. Schoppe. These two met the delegation in Oslo and organised a dinner on the eve of departure. The article then goes on to give an account of Reichsminister Todt's letter of invitation. Todt - best known as leader of the semi-official Organisation Todt responsible for development of infrastructure-had referred to the two countries' shared interests in hydro-electric development. The letter ended with a hope that the tour would give the delegates an opportunity to form their own impressions of Adolf Hitler's Germany.

Then follows Rolf's description of the 12 day excursion, a three or four page engineer-to-engineer discussion full of words such as generators, dams, reservoirs and kilowatts. There is a chronological account: 'Next day;' 'After the lecture we visited...' But there is also praise of train rides through beautiful mountain landscapes and professional enthusiasm for the way the Germans had organised and linked their power supplies, which he warmly recommended. Finally he turns to cultural life:

In Berlin, Munich and many other places we were very impressed by modern German culture, as manifested today in the new German building style, in the 
architectural beauty of the autobahns and the Olympic stadium, in fine art and in the deliberate effort to create assets that will last beyond our generation.

Finally, he adds that he doesn't think the war has affected the country very much, in fact remarkably little, he thinks, on the $3,000 \mathrm{~km}$. they had travelled, apart from 'camouflage and other air defence precautions.'

The article and the style of writing can be analysed, interpreted and misinterpreted. You can read it rather as you read the Bible. You can say that it is written by a typical Nazi, or that someone else has been directing the pen, or that it is written by an engineer who is keen to integrate the Norwegian power systems. A Norwegian reading it today would undoubtedly consider the writer to be a Nazi sympathiser. But why he had gone on the tour and why he had written the letter remained his own secrets. For Schwartz it was the evidence he needed to proceed. Was a pro-German travelogue a clever move, or not so clever? Whatever the answer, Rolf did it anyway, went on the tour and wrote the letter. 80 kroner, equivalent to a little over 200 US dollars or a little less than 200 Euros in today's values, was donated to the Norwegian Legion, the branch of the Waffen SS that was set up on the initiative of Quisling and Terboven to fight against the Soviet Union on the Eastern Front.

In summary: Appeal submitted; money donated; article written; plus a named person in the hierarchy who promised to recommend an appeal to his superiors. The year is 1942. In the meantime, Schwartz's superiors have died. Engineer Todt perished in a flying accident after his plane fell in a mysterious accident after a quarrel with Hitler. His successor Albert Speer should have been on the same flight but decided to take a later plane.

\section{And His Answer Is ...}

The following summer Rolf is back in Berlin to follow up his conversation with the Germans in the Grand Hotel. He still hasn't said whether or not he will take on the research job. If he says 'Yes,' the officers will be pleased. If he says 'No,' there can theoretically be two possible outcomes. Either the Germans will accept his refusal and send him home, or they will use harsher means to compel him to stay. They have invested so much to recruit him that the first seems very unlikely in a war situation. We can only try to imagine what thoughts go through your head when the enemy asks if you will work for them. Did Rolf see through the Germans? Was he doubtful at some point? Scared? Or on the other hand, did he think he could manage 
to deceive them? Maybe he thought only about his research. That is what he has implied to us ever since. Perhaps he wanted to help. Help who, and how? To win the war? To make medical equipment? Is he in somebody's service? If so, on which side? One or the other, or both?

What we do know is that it is wartime. He is intelligent, enthusiastic, socially established. He has a family, a wife and three children; a mother and father who are proud of him; three sisters who are fond of him; many nephews and nieces; a brother he has been close to for many years, who has now been captured by the Germans. He has a big and cohesive extended family, plus friends and professional connections in Germany from twenty years back with whom he still maintains contact.

In Oslo, daily life is afflicted with ration cards and blackout curtains. The soldiers of the occupying power are in the streets. Friends are arrested. Neighbours are abducted. Censorship and restricted freedom of speechthe very things that bothered him so much when he lived in Berlin that he moved home to Norway. It is difficult to imagine that a man such as he would not realise that taking a job in Germany now, when everything about the Germans was looked at askance, would make his problems worse. Nevertheless, he decides to take part in a German research project. Why? Is he too detached to understand the implications? Is his mind on other things? How does his mind work?

Does he think idealistically - that the research will lead to cancer treatments? Does he think politically — that the Germans have special military interests for which they want to recruit him? That the betatron will be used in weaponry? Does he ask himself how a machine that generates high energy, but not in a form suitable for weaponry, can be of any military significance? After all, he is the one who knows what it is useful for. Or does he wonder if the Germans will use it for propaganda?

Does he think personally - that the job in Germany can be used as a trump card to rescue his brother? He has already raised with the Luftwaffe officers the question of whether he can count on their support for the appeal for clemency if he goes along with them on the research project. Is he afraid what the possible consequences might be either for his brother or for himself if he says 'No?'

Does he think morally — that you just don't do that sort of thing? Don't flirt with the enemy. Should he refuse to go because it is war? Good Norwegians answer 'No' to such requests without hesitating. He is hesitating. Is he worried about what his family will think?

Is he thinking egotistically — that he will see what he can get out of it? The war cannot govern our lives entirely. 
Perhaps he isn't thinking about it at all. Perhaps it is only those around him who are thinking, wondering whether he is out of his mind. He gives them little help, doesn't share his worries, doesn't report his doubts, doesn't assert his innocence. He doesn't assure them of his good intentions. $\mathrm{He}$ knows more than he says. It is war.

1943 was a catastrophic year for the German war effort. Defeat after defeat, starting with Stalingrad. On the Atlantic, on all fronts: retreat. No longer any doubt about who would win, just a question of when. There might not be enough time to develop his betatron-whether or not it was important to the war effort.

\section{What About the Family?}

Rolf systematically started sorting out the practical details and formalities. In Berlin, the negotiations with the German officers became more specific. At that time the Allies had started carpet-bombing German cities, and Rolf made it clear at an early stage that there was no question of moving to Germany with the family under these circumstances. The delegation said that the family could continue living in Norway and offered him the opportunity to commute by air. Furthermore, he could stay at home in Norway to work on the theoretical aspects of the project, though when it came to the building of the accelerator he would have to be on site in Germany to supervise the work.

So his wife and children could stay on in Røa. Rolf would continue to be employed by the Norwegian company NEBB and would just be seconded for the project. His salary would be paid to his wife and he would be supplied with a house, food and money in Germany. All the practical details were in place, but there was much that was still not clear to him. He did not know why it was the Luftwaffe in particular that had recruited him, and he understood that his status as a foreign worker didn't allow him to know that. The delegation didn't say why they wanted a betatron, though it was obvious and no surprise to him that the German authorities were involved in a race between American and European researchers. Sharp scientific competition in the development of accelerators was not new; he had taken part in it himself. Irrespective of what use the Germans intended for the betatron, it was pretty clear that they wanted to keep up with the Americans. If the official line was that the betatron project was being set up to develop more and better equipment for medical use, that was fine. 
His sharp and methodical brain may have made sense of all these questions, but he tells us nothing about them. He didn't write it down. Only he can have known how much or how little he understood of the situation he was being drawn into, and even he can hardly have known enough. In Rolf's predicament, navigating the interface between his own life and global politics was like walking through a minefield. There were plenty danger signs, but no markers of a safe path. Only he could judge the relative risks of saying 'Yes' or 'No.' He has to make the decision alone, but the consequences of his decision will affect many.

He answers 'Yes,' on condition that the Luftwaffe officers will do what they can to persuade the security police to release Viggo. They promise support, but repeat the reservation that they themselves do not have authority in these matters. This is probably true. They can however use their influence to have him released, or at least to have his prison conditions modified. That's what they say. Does he believe them? Do they mean it?

\section{Into the Labyrinth}

The Germans had no time to lose. By August, Rolf was installed in Hamburg. Formally and officially he was now in German wartime terminology dienstverpflichtet, obliged to perform compulsory labour. In his case, however, the obligation was not just to any task but für eine besondere Aufgabe — for a specified task. His job was to build radiation transformers for the German air force at a critical time when German weaponry needed to be upgraded. His employer reported directly to Arms Minister Albert Speer. Rolf was really in the thick of it now.

The date when he started is a little uncertain, but we know that it was at a difficult time. Hamburg had recently been bombed by British and American planes in a long planned bombing operation known bizarrely as 'Operation Gomorrah.' After the biggest raid on the night between 27th and 28th July with over 700 planes, the city burned for days. It was described as resembling a stove, all red flame and black cinders. The population stayed awake all night to be ready to go to the air-raid shelters. By 3rd August it was all over. So when Rolf arrived, everybody was busy trying to clear up after the bombing. He got lodgings in a house in the outskirts of the city. The location was alright, but he missed his family, and the ruination round about him didn't make it any easier; 50,000 killed and a million homeless. The Hanseatic town of Hamburg did indeed now resemble the destroyed and uninhabited Old Testament towns of Sodom and Gomorrah. The only 
compensation was that it was now considered a relatively safe place to live, as there was nothing more left to bomb.

For that very reason, the town was deemed suitable for the Luftwaffe's new project. Moreover, there was an important factory there, C.H.F. Müller, or Roentgen-Müller. The business had been founded by the glassblower Carl Heinrich Florenz Müller. It now belongs to the Dutch company, Philips, and manufactures X-ray tubes among other things. The buildings had been more or less undamaged by the bombardment and were selected as the place for the work on Rolf's betatron, Rolf himself having been involved in the choice of location. This factory was particularly suitable both because of its glass-blowing workshop and the availability of expertise in vacuum technology. Here on the banks of the Elbe, in Fuhlsbüttel in the north of Hamburg, the first $15 \mathrm{MeV}$ betatron in Europe was to be built. Nazi Germany was paying for it.

The first person he got to know was Richard Seifert, who owned and directed an internationally recognised X-ray company in Hamburg that he had inherited from his father. Rich. Seifert \& Co. are now leading suppliers of materials-testing equipment for the aviation industry. The firm had long-standing connections with Roentgen-Müller. Seifert had originally ordered his X-ray tubes from them until he changed to having them made by AEG in Berlin, which naturally didn't please the Müller people. This however did not affect the relationship between Richard Seifert and Rolf Widerøe, either on a business or a personal level. The pair of them also socialised privately. Rolf developed great respect for Richard and later described him as able, hardworking and 'an OK chap who helped me a lot in my particular situation.' ${ }^{7}$

\section{His Own Boss}

Rolf had no direct boss. He was not supposed to know what organisation he was working for. So he still had some unanswered questions, one of which was who was ultimately and officially responsible for what he was working on. He met many people who were involved one way or another but were not directing all aspects of his work, or who had some sort of supervisory function, politically or in other spheres. Not everything was made clear to him. He himself considered Colonel Friedrich Geist from the Luftwaffe as formally responsible. Geist was the head of technical research and development in Speer's arms ministry, an important member in the hierarchy and Speer's right hand man, according to the Nobel prize-winner Werner 
Heisenberg. Rolf visited Geist a couple of times at his office. 'A decent sort, quite pleasant,' as Rolf wrote, adding 'I had no other dealings with him apart from the matter in hand.'

He did, however, have quite a lot of dealings with a small, semi-official company that worked as the link between him and the Air Ministry in Berlin which was financing his work. The head of this firm was called Hollnack. Nobody used his forename, Theodor. According to Rolf an odd, very pernickety, slightly excitable person who overwhelmed people with his interest in Nietzsche. ${ }^{9}$

But Hollnack had power. He had administrative responsibility for the betatron project and functioned as the go-between linking Rolf to the authorities. On a practical level, he was also responsible for budgetary payments for the project. Money didn't seem to be a problem, so far as Rolf understood, and he said that he and Hollnack got on alright with each other. Rolf reckoned that Hollnack appeared to be a fan of Hitler but said that they never discussed politics. Apparently it was Hollnack who put Rolf in touch with Richard Seifert, and it appears that apart from the radiation project he had various other business operations under way, to do with aluminium. Rolf was not alone in thinking that Hollnack was unusual. Whether unusual or not, he would be important for Rolf's fate over the next two years.

On a scientific and technical level, there was no doubt that Rolf was the boss. Nobody tried to pull rank on him, and 'there was no contact overhead with anybody high up,' as he said. Now there was work to be done, irrespective of why he was there. Difficult decisions or not, war or not; it was now a matter of science and technology. Now he could create the machine he had invented theoretically. He had thought through how to accelerate electrons round in a circle to a chosen speed and he was keen to see how this could be utilised.

\section{A Strong Team}

By that first autumn, Rolf already had a strong team assembled, with Dr. Rudolf Kollath, Dr. Gerhard Schumann and physics student Bruno Touschek in leading roles. They too were paid by the Luftwaffe, through Hollnack. Rolf also had the support of the experienced workers of the Müller factory. Kollath, a physicist, had previously worked in connection with the aluminium smelter in Sauda in Western Norway and had also worked in the AEG research laboratory in Berlin, though not at the same 
time as Rolf had been there. Life in Nazi Germany was difficult for Kollath, because his wife was of Jewish origin. So he was not eligible to be appointed to a university or to the official bureaucracy but had to remain in industry-or alternatively do other work important to the war effort. When particularly difficult problems had to be solved, young Touschek's creative imagination and mathematical skill were brought into play to make the required theoretical calculations. He presented the results of these in neat, typewritten diagrams. Rolf doesn't say so much about Schumann, other than that he did his job and that he didn't see him very much.

He does however tell us quite a lot about Touschek, the student. Austrian. Recently turned 20. Gifted. Jewish mother. Problems with permission to study. Working secretly for the Luftwaffe, i.e. for Rolf. Newly arrived from Berlin. Allowed to lodge with a professor called W. Lenz who was ill and whom he almost had to carry down to the cellar when there was an air-raid. He also had permission from several professors to attend their lectures at the university in Hamburg, though he could not be registered officially as a student. Rolf had already met Touschek that first summer, in Professor Lenz's flat, but they knew of each other and had been in contact prior to that. Touschek had worked part-time in the editorial department of the journal Archiv für Elektrotechnik in Berlin and had communicated with Rolf because he thought he had found an error in the calculations in Rolf's article. So Touschek knew about Rolf's work on betatrons.

Rolf started to wonder whether there was a connection here, whether Egerer the editor of the journal had brought the student to Hamburg. Previously he had had a little part-time job with the Löwe company in Berlin, where Egerer had also been employed at one time. In Hollnack's office one day, Rolf 'suddenly' met Egerer. When he had submitted his doctoral thesis to the journal editor fifteen years previously, the pair of them had only communicated by letter. We may suppose that when they now met face to face, Rolf asked the editor what had become of his second article. It is hard to imagine that he would not avail himself of this opportunity to enquire. If he didn't, that would imply that they had already been in contact in the meantime. Learning of these connections and 'coincidences' now in a historical context, it is easy to start hearing warning bells. There are just too many coincidences. Rolf never shared information with anybody else about how loudly he heard these warnings, but he has let it be known that he developed an increasing awareness of how things hung together.

Through Touschek and Lenz, Rolf also got to know Hans Suess and H.J.D. Jensen. He got on particularly well with Suess, who made no secret of his aversion to Hitler, Rolf recalled. Suess was one of the professors who 
allowed Touschek, who was also from Vienna, to attend his lectures. He was rumoured to be a communist.

\section{Fringe Benefits}

Rolf was well paid and had generally good working conditions. For the first two months he worked mainly from home in Oslo, with occasional visits to Berlin. He said more than once that from time to time he got 'leave to come home. ${ }^{10}$ At other times he seemed to imply that he could travel as often as he wanted and that he could arrange business journeys where and when he wanted. It is difficult to say how much freedom he really had, and the way he spoke about this depended on whom he was speaking to, but the fact that he was able at all to travel back and forth between Germany and Norway undoubtedly indicates that he was considered an important person. Just to travel internally by train and bus often required a specific reason and special permission. He was travelling by air, and abroad, at a time when all the commercial flights between the enemy country and his own country were gradually being closed down. There were no routine flights between Hamburg and Oslo. Little surprise that the neighbours in Røa wondered what was going on. Strange things happen in wartime.

Nowadays, in peacetime, it is difficult to imagine not being allowed to take the train where and when you will. In Norway at that time you had to have a special permit from the police if you needed to travel to stations in certain zones. These restrictions applied particularly to places near the Swedish border, lest people should escape to Sweden, and to Western Norway, from where they could escape by boat to Great Britain. Rolf was travelling to and from Germany all the time. This was obviously something special.

He has however admitted that the journeys could be problematic. For example, there was fog when he was due home for Christmas in December 1943. He had a long wait in Copenhagen and only just made it home for Christmas Eve. Some people would say that was a privileged minority problem in such times. But what are the problems that he has not told us about? Was he frightened of being arrested? Denounced? Was he ever stopped? He has not told us whether he travelled alone or whether he was followed by officers. If he was being escorted, was he frightened that acquaintances at home would see him together with somebody in German uniform? For all we know, he may have had a German uniform himself. 


\section{Everyday Life at the Factory}

The leader of the section of the Müller factory working on the betatron was Alberth Kuntke. He had been an apprentice at Rich. Seifert \& Co and had transferred to Müller where he trained as an engineer with support from the company. Rolf liked him, and visited him privately several times, in a house in a wooded area outside Fuhlsbüttel. Rolf described the morale in the factory as good and he described the employees as well disposed towards the incomers. Several of the fellow-workers were highly trained specialists who carried out free-standing projects for Rolf.

Among those he worked closely with were the second in command at the factory, who was an X-ray specialist, and two or three of the engineers. The second in command was clearly a specialist in something quite other than $\mathrm{X}$-rays, and Rolf thought that he had been given his management position for political reasons. As a Philips company, Müller was subject to Zwangsund Fremdvervaltung, the regulations governing the management of foreign workers. ${ }^{11}$

According to Rolf, some of the employees were ardently pro-Nazi and outspoken supporters of Hitler. One of these was the head of the development laboratory, the physicist Walter M. Müller with whom he had quite a lot of dealings. Müller always signed his name simply as 'Dr. Müller,' but he was not related to the founders of the company. Rolf described him as pleasant, clever and popular, but made a note to himself that he must be very careful in his dealings with Müller because of Müller's Nazi sympathies. ${ }^{12}$

Rolf often travelled around in Germany, particularly to Berlin and Mannheim, but his co-workers in Hamburg knew what they had to do. Rolf had established the framework and given general directions.

\section{The Writing in the Sky}

One of the first times Rolf was home in Norway, in late summer 1943, he took Ragnhild on holiday to Tuddal Mountain Hotel in Telemark. He hasn't told us whether the children were with them, but the job certainly was. At the back of his mind, as always, were the technical problems he was facing, and especially one that he had been pondering for a long time. As often happens with creative people, when he allowed himself to expand an idea and think around it everything he saw and heard seemed somehow to connect with what was at the back of his mind. One day he dozed off on the lawn 
at the back of the hotel. While he was lying there on his back, looking up at the clouds, the solution was suddenly there above him, if not written in tongues of flame at least displayed very clearly; the rays should be made to collide! Think of the momentous forces!

He has recounted many times the picture that he saw above him: a cloud had been transformed into a stationary car, and another into a car that came roaring in and collided with it. Then another picture: two cars both moving towards each other. Bang! Crash! A much more dramatic collision. Much greater damage. Debris in all directions. In Rolf's imagination the cars are bundles of particles that are accelerated and shot towards each other. They collide, and something happens. Rolf has made one of his life's discoveries, the idea of investigating nuclear reactions in a completely new way. Physicists had for a long time been interested in studying the properties of the atomic nucleus by studying the effect of shooting particles into the nucleus. The higher the energy of the projected particles, the greater the possibility of discovering something about the atomic nuclei. Now he would make a special device to store accelerated particles in 'storage rings' and shoot the rays of particles against each other. Then he would be able to observe and study the nuclear reactions.

Back in Hamburg after the visit to Norway, Rolf excitedly told his assistant about the brilliant idea he had had while on holiday. His assistant was not impressed in the least. What the boss had found out was already well known and was something everybody learned at school—indeed, at primary school. How did he imagine he could patent such an idea? Rolf, however, did what he always did. He took his idea for a patent to his friend Ernst Sommerfeld, and together they registered a patent for the principle of storage rings; Speicherring-Patent no. 876 279, dated 8th September 1943. This would later be the basis for CERN's decision in the mid 1960s to build the intersecting storage ring ('ISR') accelerator, the world's first hadron collider. Difficult for non-physicists to understand, but outstanding among his list of achievements. We don't always recognise the wisdom of our seniors, but somebody must have realised the significance of the idea despite the assistant's negative comments, because the censoring authorities declared it secret. Nobody asked why. It was war.

But Rolf took Touschek's comment seriously and said nothing in the patent about 'the desired energy balance from a frontal collision,' since this may have been considered as already known at the time. Touschek, for his part, felt slightly offended that Rolf had registered the patent when he had advised against it. Rolf's idea didn't really play a very big role in physics at the time. He realised that the time was not ripe to construct such an 
apparatus. New technologies and new equipment would need to be developed to bring it into being. It was questionable whether he would ever profit from his patent. The only particle accelerators he knew of that could be used for such an apparatus were the betatrons that Kerst had developed in America. They were basically suitable only for working with electrons. It appeared to be only a matter of time before there would be storage-ring accelerators for other types of particles, quite different from the existing cyclotrons. He didn't know then that it would be a good ten years before anyone took up the question again.

In applying for the patent, Rolf was not concerned about the not-yet-existing technology. What he was interested in was the principle. That was what he wanted to secure for himself for the future. He set aside the vacuum problem he was struggling with - at any rate until later. It had been problematic for him for a long time, and he could hardly ignore it, but for the time being it was unsolvable. An even better vacuum would be needed for particles to be stored longer without colliding with molecules of the residual gas. He also understood clearly that the beam path was not stable enough. He had been aware of this since his student days and he knew just how difficult it was to stabilise them. Kerst had been the first to find a practical solution to this problem. The challenge now would be to get particles with the same charge to go in their specified direction within the same tube. Rolf responded to this by thinking up an imaginative solution which at first he hardly really believed himself. The particles would be directed by electric fields. Then he discovered that it is easier to use two rings with magnetic fields to steer the particles. However, none of these 'little details' altered the fact that the best way to obtain energy from the accelerated particles would be to have them collide head-on. Perhaps, just maybe, one day, it could be achieved. Touschek was not so enthusiastic, but he didn't succeed at all in damping Rolf's enthusiasm.

Storage rings were not the only things Rolf was busy with. He was in a flurry of activity. Already on 15th July he had submitted his very first betatron patent (no. 889 659) about the injection system for the betatron, clearly a sequel to his doctoral thesis. On Thursday 2nd September he sent in two applications, betatron patent no. 2 for 'electric lenses' (no. 927 590) and betatron patent no. 3 for 'pre-magnetisation' (no. 932 194). On Saturday 4th September he signed the application for betatron patent no. 4 for 'counter-magnetisation' (no. 925 004). The holiday was definitely over. In the midst of all this he was working on his next big invention and also managed the following week to send in the Telemark patent, which became legendary. 
He had sent off all these five patent applications since coming back from Norway. Only the patent adviser in Berlin knew about this. The Müller factory and Philips the parent company didn't get to know about it. They probably didn't hear about the next patents he took out in Germany either. ${ }^{13}$ He registered altogether 13 patents between 1943 and 1945. ${ }^{14}$ Nor did the Müller personnel know anything about the patent applications on similar themes, seven in all, that one of their own people, Development Manager Dr. Walther M. Müller, had written and apparently submitted. Things were happening behind the scenes. It was war.

\section{Working from Home}

Rolf's working pattern evolved. He found that when he was at home in Oslo he had peace to concentrate on thinking out new ideas, writing reports and lodging patent applications. The work on the betatron continued at the same time, but for the time being his role consisted mostly of design and calculations. Kerst's first betatron was only $2 \mathrm{MeV}$. Rolf's model was stepping up to $15 \mathrm{MeV}$, which he considered to be quite a short step. Rolf and his team really wanted to achieve an energy range as high as possible, but they reckoned that by restricting themselves to a maximum power of $15 \mathrm{MeV}$ they could probably avoid some technical problems. It had already been decided in early summer that the betatron they were now building in Hamburg should be a relatively small machine. Building a bigger one somewhere near Mannheim could be considered as part of the next round of development.

During September he prepared a report in which he summarised the most important steps in the development of the type of betatron they were now building. In the report, he starts with his own ideas from when as an enthusiastic student in his twenties he thought of the solution. Now he was twice as old and in the process of realising his dream. Then on 5th October he submitted his fifth betatron patent application of the autumn. This consisted of an addition to the patent for electric lenses from the previous month, showing how magnetic lenses could be used to stabilise the beam path. This would become a forerunner to an important invention he made later; strong focusing, which would be important in the work at CERN when the war was well and truly over and the time was ripe.

Rolf kept his 1943 patents secret. We don't know whether it was the Luftwaffe who required him to do that. He might have kept them secret for his own benefit, but he did apply for German patents rather than 
Norwegian. He could have applied in both countries. There is obviously someone who is not supposed to know. But somebody knows something. Brown Boveri are in the know and involved-though not with all the patents.

\section{A Tug-of-War Over the Contract}

Rolf soon learns that a German was not just a German. Some were Nazi supporters and some not, but there were also other distinctions complicating the picture. Even though the work was well under way, the contract negotiations between Rolf and the German authorities had still not been concluded. The patent rights were part of the disagreement. High level discussions were probably taking place meantime about Rolf's patent rights and terms of employment. There exists a draft agreement, probably written by Rolf, dated 19th October 1943 and put into legal language by an advocate in Essen. We don't know, however, whether this version was signed. Probably not. We don't even know whether any formal agreement was ever signed.

The draft, though incomplete, is in the form of a contract between Rolf and the 'Schiebold Institute.' The institute was run by a triumvirate of Ernst Schiebold, Theodor Hollnack and Richard Seifert. It worked for Field Marshall Erhard Milch, who was a man of some importance in the Third Reich. At that time Milch had a dual appointment, both as Generalluftzengmeister responsible for armaments and other equipment for the Luftwaffe and as General Inspector of the Luftwaffe. In other words, he was one of Göring's most trusted and influential immediate subordinates.

The draft contract was ordered by Schiebold and deals with the rights and duties Rolf would have from his position as an enlisted foreign worker, someone who has Dienstverpflichtung durch den Reichskommissar für die besetzten norwegischen Gebiete, 'service obligation through the Government Commissar for the occupied Norwegian territory.' According to the draft, Rolf would among other things assign all his already submitted German patents and all future patents together with all further relevant technical developments to the full disposition of the institute. The contract would apply for at least three years from when it was signed. Appended to the draft there is a list Rolf himself had made of the six betatron patents he had registered up till then since coming to Germany. ${ }^{15}$

This indicates that Schiebold certainly knew and Seifert and Hollnack probably knew about the patents Rolf had applied for in Berlin. Irrespective 
of what was included in the contracts, we can understand that it was a difficult balancing act. Not everybody was to know everything, and some people may have had hidden agendas. Major industry has its own ways of pulling strings, and Rolf may have had to make concessions for other reasons.

He subsequently remained silent about the question of the contract, and he said nothing about it to Pedro Waloschek in connection with the biography. Waloschek himself has said:

I can find no evidence that this agreement was ever concluded.' However, the conditions that are described in the draft correspond with the conditions he was actually living under in Germany. His freedom of movement, for example. The page about payment is missing, but he never complained about his remuneration. ${ }^{16}$

\section{Three Phases}

By November, Rolf and his team had progressed far enough with their preparations and preliminary calculations to be able to begin the actual construction of the betatron. During another trip home to Oslo he had prepared a production schedule for the manufacture of betatrons in Germany. This was a four-page document entitled: Vorschläge über eine möglichst rasche Durchführung von Konstruktion, Bau und Aufstellung des Strablentransformators, in other words a betatron plan from A to Z.

He scheduled the work in three phases. The first was to do with the design and manufacture of the $15 \mathrm{MeV}$ betatron in Hamburg. The second phase was to be the design and manufacture of a $200 \mathrm{MeV}$ betatron, and the third and final phase would be the design and equipping of a test laboratory in Ostgrossheim for possibly even bigger installations. He specified the work plan and staffing requirements for each phase. He confirmed that the first phase was already under way at the Müller factory in Hamburg. He explained how the various components of the $200 \mathrm{MeV}$ machine would be made, and that that would take 10-12 months. At the same time, preparations would be made for the research centre at Ostgrossheim so that work on the 200-machine could start there after approximately 12 months.

Rolf was writing with tongue in cheek. He mentioned Ostgrossheim, but didn't name Schiebold. He couldn't do that, because that would be to declare that he knew about aspects of his project that he was not supposed to know about. But he was informed of the existence of the research establishment at Ostgrossheim and must have cleared this with the highest 
authority, to be able to include it in his plans. There was however a lot he didn't know. One word he soon learned was 'death rays.' Another was 'ray gun.' If he had known the full story, what would he have done then?

\section{Death Rays}

It was difficult to know what to make of Schiebold and Hollnack. One was such a fantasist and the other such an ardent Nazi. Indeed, they both appeared to have strong Nazi traits. It was Hollnack who had introduced Rolf to Schiebold the physics professor, just as he had put him in contact with Seifert. This was a remarkable acquaintanceship. Rolf was officially not supposed to know about the top-secret arms projects, but Schiebold was responsible for the research centre that was under construction at Ostgrossheim, and he can hardly have kept the reality of this concealed from Rolf.

So Rolf did know about Schiebold's big death-ray project, the idea of creating a massive X-ray canon that would secure victory for Hitler. Formally, this was the project Rolf had been brought in to work on. The betatron was part of the whole plan. So he understood why the Luftwaffe was interested in his betatron. Ernst Schiebold was the brain behind it, the man with the wild idea of a death-ray weapon. ${ }^{17}$ Schiebold was a specialist in X-ray testing of materials, and it was he who had launched the idea of using X-ray guns against enemy aircraft. The idea was to create an X-ray tube with high enough voltage to generate high-intensity rays even at a distance. Thus it should be possible to kill the enemy pilot or detonate the bombs the plane was carrying.

Schiebold's death-ray project was motivated by the same vision that inspired the Peenemünde project with its almost impossible levels of human and economic investment, the V1 and then the V2 rockets. Urged by a combination of desperation and war propaganda, Nazi Germany put its trust in another wonder-weapon, Schiebold's death rays. To eliminate enemy planes before they approached their target would be the dream of any air force. The idea of silent, invisible rays from the world of science fiction fascinated not only Göring in World War ll but also Khruschev and Reagan in later times. Reagan's Star Wars project was based on the same ideas about long-distance rays that underlay the German war-machine's project. Scientists with varying levels of belief and loyalty were part of Schiebold's organisation, and it was a curious irony that the regime's plans were dependent on many of their 
scientists, many of whom were Jews, being released from forced labour or set free from the concentration camps.

However, Nazi Germany was not first in coming up with the idea of mysterious, fatal rays. An Englishman had suggested it in 1935 with a proposal for strongly focused electromagnetic rays. ${ }^{18}$ Every child who has played in the sun's rays using a magnifying lens to set paper on fire understands something about the strength of concentrated radiation. But from igniting a scrap of paper to striking down a plane from the sky is a big step. The English soon abandoned the idea as beyond technical possibility. Then several years later Professor Schiebold worked tenaciously to convince his colleagues and the authorities about the feasibility of his X-ray canon. He succeeded in persuading the key people in the Luftwaffe, and that led to Rolf being recruited to Germany.

\section{How It Began}

It had all started on 5th April 1943, several months before Rolf arrived on the scene that summer. Göring's right-hand man, Field Marshall Erhard Milch, received a strange note in which Professor Ernst Schiebold from Leipzig made a formal proposal 'for the attack and destruction of enemy planes and crew' with the help of 'X-ray and electron beams.' ${ }^{19}$ The full title of the note is even more elaborate and striking in its tone. The content was comprehensively presented and formally everything appeared to be in order. Schiebold was known both within the Air Ministry and to Milch personally, having previously carried out assignments for the ministry. He was a specialist on X-rays, though not specifically on X-ray tubes.

In the memorandum, Schiebold described different types of radiation and ways of generating high beam energy, for example using a cyclotron, but he didn't specifically use the word 'betatron.' The goal he suggests is ambitious; a weapon that would be able to strike aeroplanes from a distance of many kilometres. This would require high energy, and to achieve that would require more research. Schiebold also provided a list of the types of specialist he would need. The first he named was Richard Seifert with his own company in the X-ray and electrical industry. Rolf is not named. The proposal was wild but alluring, and it captured the attention of the people to whom it was addressed. The first official meeting about the project was held in Hamburg as early as 17 th April, when Seifert presented a three-page report claiming that it should be possible to develop the weapon within one or two years. Time was vital. 
Two days later Schiebold wrote a five-page supplement, and two or three weeks after that he had been awarded the contract and provided with 150,000 Reichsmarks. The project was to be based at the Luftwaffe airfield at Ostgrossheim. By the following day, 20th April, he was given the opportunity to give an oral presentation of his big idea to Theodor Hollnack, whom he knew from a previous research contract. Milch gave full authority. Schiebold followed up with several more supplementary notes, and the project was under way. Obviously top secret. With Schiebold as scientific head, Seifert as technical adviser and Hollnack as administrative manager. However, it was not so secret as to prevent many people knowing about it, not least because Schiebold couldn't hold his tongue. Important physicists such as Arnold Somerfeld and Werner Heisenberg were among those who knew.

Components for the manufacturing site were ordered from Siemens, who made some themselves and had others made by Osram, which was part of the Siemens Group and still had some links with the Löwe company in Berlin. There was also a connection with AEG, who collaborated with General Electric in the USA, so far as this was possible during the war.

There was also a personal background to Schiebold's project, which enhanced the drama and made it even more important for him to succeed. He had previously managed a semi-official research institute at the University of Leipzig, which had been razed by the Allied bomb attacks. His house had also been destroyed. He lost nearly all his equipment and probably also the documents relating to the X-ray cannon and all the correspondence he had had with Seifert, Hollnack and Widerøe. He was left standing on bare ground, without a house and without any base for his work.

Then Schiebold turned his attention towards Ostgrossheim in northern Bavaria, quite a small town $45 \mathrm{~km}$. south-east of Frankfurt. He and his colleagues took what little was left of the research institute and built up a new laboratory in temporary, bunker-like locations on the abandoned military airfield there. The main hall was completed by New Year 1944, ready for the $15 \mathrm{MeV}$ betatron to be installed there once it had been built at the Müller factory. An unused X-ray apparatus was brought from a hospital in Hamburg, to be used for experiments in the meantime. Hollnack arranged the finances. Great things were to happen here. The Luftwaffe's researchers were on the offensive.

Even though much was kept secret, Rolf gradually learned more and more. Much later, when asked directly whether he knew when he was taken to Germany that the betatron was to be used in connection with weaponry, 
he answered 'No.' Quite the contrary, he was led to believe that it was a civil project.

I didn't suspect anything at that time about the business with Schiebold and that it was the anti-aircraft weapon that was the basis for the project. I didn't know anything about that either, because it was so terribly secret. I was not allowed to hear anything about that. ${ }^{20}$

He repeated that in the biography:

In any case, I didn't know at that time that anybody would want to use betatrons as weapons. I wouldn't even have believed it was within the bounds of what was possible. They obviously had a strong argument: they wanted to overtake the Americans, irrespective of whatever other use betatrons would later be put to. The official line was that all this was being done to develop new and better $\mathrm{X}$-ray apparatus for medical use and for non-destructive testing of material. ${ }^{21}$

So whom should we believe? There are false explanations, hidden agendas. Add in a dose of mystery, a dash of wishful thinking. Spectres shimmer in the light of day. Some of the mixture is not mysterious at all, just propaganda. People going their own way appear so trustworthy that nobody suspects them of anything. Some overstate their case to the point of incredulity.

Who is who? What is real? Whom can we trust?

This is war.

\section{Schiebold on the Carpet}

A new person trusted by the ruling powers came into the picture. There is reason to take note of this man, whom Rolf mentioned several times in interviews. Professor Walther Gerlach was given responsibility for all nuclear physics and for the secret German atom project run by the 'Uranium Club' consisting of carefully selected researchers. In addition, and of particular relevance in Rolf's context, he was chairman of the management board of the Luftwaffe research station at Ostgrossheim. The board was responsible for supervising Schiebold's activities. The other members of the board were Hollnack, Heisenberg, Egerer, Geist, Esau, Fennel, Georgii and Seifert. 
Quite soon, things began to fall apart. The chairman was uncertain about the development of the radiation project and turned to Professor Helmuth Kulenkampff for advice about what he called a 'top-secret' project. Kulenkampff, who had been Gerlach's Ph.D. supervisor, scrutinised the ray-gun idea in detail. He found out that the radiation did not seem to be as Schiebold had presented it. For example, it would be impossible to use the weapon at the range that had been claimed. Kulenkampff's severe criticism of the project reinforced Gerlach's doubts. As they both agreed, Kulenkampff sent a letter to the highest relevant authority, Field Marshall Milch. This was a brave move, as it showed that the chairman had failed in his obligation to keep it all secret. However, Milch replied with a personal letter expressing thanks that somebody had shown courage and come to such a clear decision about the matter.

Walther Gerlach was a key figure in what happened next. Along with Werner Heisenberg he was one of the most influential scientists in the Uranium Club. His record in the politics of research shows that he was also an important worker for Nazi Germany. From 1st January 1944 he was head of the physics section of the National Research Council and the council's agent for nuclear physics. Under the jurisdiction of the council there was a special group set up to be responsible for research in physics, with significant input from the electrical industry. So it was no surprise that energetic and efficient Gerlach was also appointed chair of the management board of the Luftwaffe's research establishment, the high voltage installation from which great results were expected not only in biology and physics but also and primarily in the form of the radiation gun.

When the National Research Council was set up a couple of years earlier, the purpose had been to bring all research together, both basic and applied. After a while, Marshall Göring became president, with the idea that he would govern the research with the same discipline and effectiveness as he governed the air force. At the same time, the council was moved from the education department to the national department for munitions, where Albert Speer who had taken the initiative for the re-organisation was himself the minister. These changes were a turning point for National Socialism's relationship to science and particularly to Jewish researchers. Till then, there had been a sort of tacit agreement that Jewish researchers must not be sent away from Germany, because the nation needed their expertise. No such grace would be shown now; Jewish scientists should be removed. 


\section{Interrupted by the Air-Raid Sirens}

At the Müller factory in Hamburg, the construction of the betatron continued. Some of the equipment was supplied by Seifert's company and some by Brown Boveri. The realities of war did however impede the manufacturing process. When the sirens sounded, everybody had to go to the air-raid shelter, and the vibrations caused by the bombing were a problem for the sensitive apparatus. In the shelter, there was not much to do other than to think and to let imagination run. Always calm and positive, Rolf described this as good thinking-time. So the time in the cellar also had its advantages, or as he later expressed it laconically: the war gave him the opportunity to spend a lot of time meditating about how to improve the accelerators and thinking out new ideas. But he doesn't conceal the fact that when they came up again they were always worried about whether there was still a vacuum in the tube they had been working on when the alarm sounded.

It soon became clear that the size chosen for the betatron was correct from a technical point of view, as Rolf had thought. By restraining themselves from going for a higher voltage, they avoided some problems. Another reason was that the level of radiation in the laboratory was sometimes quite high, which could cause difficulties. On 8th February he presented a secret report both about the present betatron and about the plans for the future, massive one.

Around him, however, things were slowing down. Already towards the end of February, possibly on the 22nd, Gerlach called a meeting of the Ostgrossheim management board. As leader of the research centre, Schiebold was not a member of the board. Neither was Kulenkampff or Rolf. They could only attend when invited, but they did have the right to speak. They were at the meeting in February, where Kulenkampff was clearly critical of Schiebold's project. His criticism was set out in a written document presented to the board members, but Schiebold himself was not given a copy. He had just prepared a general progress report for the board and he was completely surprised to learn that the board was putting a question mark on his project. Admittedly, he had got into a quarrel a few days before with one of the board members, Georgii, who was also in the Luftwaffe's research management team. That was a warning, but not sufficient for him to take seriously. In a letter to Georgii on 29th February, Schiebold tried to explain the situation and expressed a hope that the disagreement would 
blow over. But the criticism at the board meeting created unease about the whole project, and Rolf's 'minder' in the system, Hollnack, began to sense the uncertainty.

Schiebold was informed that his institute could only remain in Ostgrossheim until further notice. The deadline was set for 1st April 1944. By then, his Institut für röntgengen ologische Roh-und-Werkstoff-Forschung would need to be out. Eviction was bad enough, but worse was the loss of prestige in not being the first person to know about it. It began to dawn on him that he no longer had full support and that he would need to do something to show his strength. On 4th May he wrote a new, enthusiastic account of Rolf's betatron, plus a comprehensive ten-stage work programme for the research centre at Ostgrossheim.

\section{Another Setback for the Death-Ray Project}

Gerlach immediately called a two-day board meeting in Berlin, at which the programme was cut back. Schiebold's plans for a death-ray canon were declared impractical and cancelled. Rolf's project, on the other hand, was not subjected to criticism. Many of the contemporary documents from this period are no longer preserved, but we know that there was an important meeting on 6th May and that in addition to the board members, Rolf and his colleague Schumann took part, plus Kulenkampff, Schiebold and two others. ${ }^{22}$ As chairman, Gerlach made a note for his own use, both of this meeting and of a later meeting on 15th August. The note is dated 25th August. No other reports have been found, and Gerlach's note is not an official minute, just a personal view. Schiebold's son has later made available a photo of the six pages that Schiebold took with his own camera. Put briefly, the content asserts that Schiebold's project didn't measure up. ${ }^{23}$

Schiebold had been given a final extension of his deadline to 12th July to produce further calculations to try to prove that he was right. Messages went back and forth. Kulenkampff was still not satisfied. In addition to Professor Gerlach, several others began to admit that they had been sceptical. Heisenberg and Sommerfeld had also thought for some time that what Schiebold was asserting about death-rays was unrealistic. They were both experts in applied physics, looking at the matter from a practical point of view, but the theorists, such as Rolf's assistant Bruno Touschek, were tending in the same direction and three of the experts at the Müller factory have later said that they had thought right from the start that Schiebold's $\mathrm{X}$-ray cannons were unrealistic. In their eyes, Schiebold was just a pompous 
eccentric with some high-flown and politically correct ideas. They had only been interested in the project because of the prospect of working on a contract that had been assigned high priority for the war effort. ${ }^{24}$

Kulenkampff led the way with his criticism, and his assessment then influenced Seifert and Hollnack, who had initially felt positive towards Schiebold's proposal. Both were now distancing themselves from the original plans. The board confirmed clearly that they wanted to proceed with the other parts of the contract. The grand project for which Rolf had been recruited was now torpedoed, and its author out of the picture. But Rolf was to continue, not with death-dealing rays but with life-giving rays, as Pedro Waloschek put it. Rolf's project was secure.

Schiebold's motives for wanting to build a death-ray weapon are unclear. Was he perhaps just a mad scientist wanting to exploit the situation to make his name with his own weird invention? For a fair and balanced judgement, we must recognise that he was originally a serious and respected physicist. The question is whether he really believed in the wonder-weapon himself, or whether he was using it as an excuse. The answers to these questions remain obscure. We may also wonder to what extent he regarded Rolf as a member of his team and to what extent Rolf was 'part of the package' in advancing his plans.

This was Rolf's explanation, many years later:

Most people thought that this was an example of a relatively harmless man, without doing anything wrong, thinking that there could be something, if not exactly practical, that he could do so that he could perhaps get a little money, so that he can do some research. So they had expressed themselves a little vaguely about this project. Enough of that, he went to the Luftwaffe and said: "Here is a machine that can shoot down planes. We've got the death-ray. Alternatively, we can detonate the bombs up in the plane if we send enough energy up there, or we can kill the pilot or render him unconscious or something like that." The air force supported the idea, and they built a research establishment that they set up on a little airfield near Frankfurt. I don't remember what it was called, but I can find out. ${ }^{25}$

\section{More Betatrons}

The fact that Schiebold's project with the special X-ray tubes was finally stopped didn't mean that the Luftwaffe lost interest in high-energy radiation. Far from it. Gerlach, the national research council's agent for nuclear 
physics, was keen to continue and more projects followed. Siemens also had betatron projects financed by the national research council. Just a few months after the American, Donald Kerst, achieved his goal of building the world's first betatron, Siemens had already started on their first. Two further contracts followed soon after, to begin the research and development work on a rather bigger betatron, $20-25 \mathrm{MeV}$, and to start planning for a $100 \mathrm{MeV}$ version. So in spring 1944 Siemens was working on three betatron contracts for the Luftwaffe. These were long-term projects considered as investments for when the war was over. Gerlach no longer thought that there would be any military use of betatrons to generate death-rays. ${ }^{26}$

There were also several other projects going on, though they never came to completion. In autumn 1943 the national research council had awarded Heinz Schmellenmeier in Berlin a contract to build a small, $1.5 \mathrm{MeV}$ betatron for medical use. He had his own history in relation to the war. He had worked to oppose the Nazis ever since 1935 and had been in prison for several months because of his illegal activities. To avoid being conscripted into the army, he had started a private military technology company, Dr. Schmellenmeier's Development Laboratory. One of his fellow-workers was Richard Ganz, who was of Jewish origin and whom the Nazis wanted to catch. Ganz was what was described in those days as 'a privileged non-Aryan person,' and Schmellenmeier almost certainly saved his life by employing him on the project when he was already on the list of Jews destined for the concentration camps. ${ }^{27}$

Two others, the later Nobel Prize winner Walther Bothe in Heidelberg and a colleague, had ideas for a $10 \mathrm{MeV}$ betatron but never got it beyond the planning stage. Bothe was an important member of the Uranium Club, and together with his assistant Wolfgang Gentner-with whom Rolf would later work on the plans for CERN-he had constructed the first German cyclotron, a forerunner of the particle accelerator. The cyclotron was put into use in Heidelberg in autumn 1943. Bothe told Albert Speer that the machine was for medical and biological research. In later years, Rolf came into contact one way or another with all these pioneers of accelerator development.

\section{Time up!}

The very final deadline for Schiebold's death-ray fantasy had expired. He had produced a 41 page document in response to Kulenkampff's critique, but it was to no avail. Gerlach invited him to a meeting on 15th August 1944 
in Ainring in the very south-eastern corner of Germany, at the institute headed by Professor Georgii. Also invited were the physicists Heisenberg, Kulenkampff and Seifert plus another from the research council, plus Geist. At least four of them, if not all, could be said to be also representing the authorities. Heisenberg was unable to attend, and Colonel Geist sent Schumann in his place. It is unclear whether Rolf was there. The main conclusion of the meeting was that there was no indication that Schiebold's plan could be of military use. This had long been the perception, and administrative measures were now set in place following the decision. Schiebold had not fulfilled the obligations as documented. This was now formally confirmed. ${ }^{28}$

A final meeting was held and sharp letters exchanged. Schiebold responded to the criticism on 20th September with an angry 15 page declaration in which, among other things, he referred to his mandate from Field Marshall Milch. This stimulated an equally forceful reply from Kulenkampff. All Schiebold's followers had deserted him. It was obviously no advantage to him that his original excuse, Milch, had gone-dismissed first from his position as Secretary of State in Speer's ministry in June 1944 and then in January 1945 from his position as Inspector General of the Luftwaffe.

Rolf tells us that he was present at this last meeting, which was held at the institute in Berlin where Heisenberg was a professor:

In autumn 1944 I was invited to a meeting at the Kaiser Wilhelm Institute in Berlin, in an amazing garden and with many physicists present. I think it was Heisenberg who had convened the meeting - or maybe Gerlach. This was an exclusively scientific conference, where we spoke freely and said exactly what we thought. As there was nobody there from the Gestapo, nothing was kept hidden. ${ }^{29}$

Pedro Waloschek is not so sure that Rolf really was allowed to attend the whole of this important meeting, and says that on another occasion Rolf had told him that he was only allowed to attend certain parts of the meeting and that he spent the rest of the time strolling in the garden. Rolf may have mixed his memory of this occasion with recollections of the meeting he had attended on 6th May when the issue came to a head. However, he undoubtedly understood the implications of the outcome of the meeting both for Schiebold and for himself:

Everybody was in agreement about dismissing Schiebold's fantasies as unrealistic. However, the meeting confirmed that the betatron was a very interesting 
machine, both for medical use and for future nuclear physics research. The hopeless "secret project" of shooting planes down with X-rays from betatrons was then (or perhaps even before this meeting) completely abandoned. However, the development of betatrons was to continue. The official basis that this was an important medical development could be retained. ${ }^{30}$

That is what Rolf says in the biography. In the interview with the physicists in Oslo he was invited to expand on what he had said about his part of the project being approved to continue. He was also asked if the discussion at the Kaiser-Wilhelm Institute really was entirely scientific and not political:

Yes, purely scientific. And it was an absolutely great and OK meeting where everybody said what they thought. I mean, there was nobody from the Gestapo nor anything secret about it.

The death-ray project was abandoned at that meeting, wasn't it?

Yes, completely dropped.

But the Luftwaffe, did they then drop their support for your project?

Not at all, we were to go on building our machine. We were to complete it, and that was how things stood. It didn't really cost a lot of money, and anyway money wasn't an issue in Germany at that time. ${ }^{31}$

By May 1944 Rolf had progressed far enough with his project to begin commissioning the betatron as planned. It worked! The radiation intensity was not very high to begin with, but eventually the measurements showed that the radiation produced had an energy level between 12 and $14 \mathrm{MeV}$. So they were approaching the goal of $15 \mathrm{MeV}$. The team succeeded in attaining this during the summer. The first European $15 \mathrm{MeV}$ betatron had been built, and Rolf was proud of what had been achieved. In addition, and possibly even more significantly, they had moved up into the same class as the Americans and could consider themselves on a level with Kerst and his betatron number two, which accelerated to $20 \mathrm{MeV}$.

Components for two betatrons had originally been ordered from the Müller factory. The first was to be used just to investigate the properties and possibilities of such apparatus. The second was for medical use. All further work with the betatrons would now be in connection with the expected advances in medicine and in nuclear physics research. Milch and Schiebold were out of the picture, but Seifert and Hollnack had full authority from the Luftwaffe to take Rolf's plans forward. So he was saved. Gerlach obviously had no objection to the Luftwaffe continuing to support the building of Rolf"s betatrons; in fact quite the contrary. Several of the members of the 
now dissolved Ostgrossheim board were in the air ministry and agreed with their former chairman.

But was the Luftwaffe really interested in making medical equipment? Or was that just a pretence? One possible interpretation is the simple principle that one part of the project should not necessarily be abandoned just because another part didn't measure up. The agreement, even though we don't know whether it was ever formally signed, was for three years. So in relation to that, the employment should continue. One can also think of more sinister explanations. Whatever the answer, work on both the Siemens betatron and Rolf's Brown Boveri betatrons continued.

At Peenemünde, the work on the new rockets was also continuing. On 6th September the first V2 rockets were fired on London. The war was in its final phase.

\section{Heads Roll}

From 20th September, Schiebold's name disappears completely from anything to do with the X-ray cannon. It is not found anywhere in relation to later work for the Luftwaffe. ${ }^{32}$ From October 1944 the Luftwaffe's research station at Ostgrossheim no longer existed; it disappeared with Schiebold. However, not everybody was against him. Karl A. Egerer, the editor of the journal Archiv für Elektrotechnik published by Springer, had good contact with Schiebold. There is evidence for this in several letters, including one where he comes to Schiebold's defence, saying that Schiebold alone cannot bear the responsibility, as he had other scientists working with him. From the letters, it is evident that Egerer agreed with the technical advisers and the people who were close to Milch. Egerer mentions among other things that it was he who had got Milch to include Rolf's ideas in Schiebold's original research project. This confirms that there was a close relationship between the editor and Milch.

Does the solution to the mystery of the disappearing article - the one that was never published-lie here? When the editor received Rolf's second article, did he take it straight to Schiebold so that it was then stamped 'secret' and became part of the Luftwaffe's radiation project? Or was it perhaps not the editor who stopped it from being published? Moreover, why did Rolf not do anything to find out why it was not published? Or did he make enquiries that he hasn't told us about? Perhaps he even found the answer. There are still many unanswered questions, and some of these are connected with his brother's imprisonment. 


\section{A Visit to Viggo}

Viggo had been moved to Rendsburg prison camp, near Kiel. Rolf visited him there; was able to meet him face to face. Viggo was not in a good way. He was exhausted and looked ill; probably a combination of malnutrition and pneumonia. Rolf's contacts had obviously not had enough influence to have his brother released. They may have done what they could, but at any rate it wasn't enough, he maintained. He hasn't said anything about how much they had managed to have Viggo's conditions improved, but Viggo had been given slightly better food and after a while he was sent on to a camp near Darmstadt where he was allowed to work out in the woods. Rolf thought that this helped him. Prior to the term in Rendsburg he had spent a couple of years in Fuhlsbüttel in Hamburg. Finally, he was sent to Dreibergen and then Dieburg where he remained until he was liberated by the Americans in March 1945. ${ }^{33}$

Nor does Rolf say anything about how he came to be allowed to go into the camp to visit his brother; whether the Germans saw the permission as a gesture of good will or were using it as a threat. It was hardly a random event. On the contrary, it suggests that the Nazi authorities were playing a game with the brothers. Afterwards, Rolf reported that he had visited Viggo, but he didn't embellish the misery and he didn't admit to whatever impact meeting his brother had on him. It is also uncertain whether Viggo knew at all that his brother was in Germany, when Rolf suddenly appeared in the camp. Prisoners in correction camps were subject to stricter rules than other prisoners, with longer intervals between being allowed see visitors, receive packages and letters or write to their families.

Two brothers in their forties, who had grown up together in a wealthy Oslo suburb; played with electric circuits that short-circuited leaving their German grandmother sitting upstairs in the dark; who had done ski trips together in the hills and woods around Oslo; who as youths had drunk beer with classmates during Easter holidays in the Alps; founded an airline together; married and raised families in parallel; settled in the best quarter of West Oslo; each made a career in his own sphere.

They have not seen each other now for two or three years, and here they are meeting in Germany, in a correction camp-one a prisoner of the enemy and the other an employee of the enemy. Viggo had little reason to believe anything other than the worst as he sat in prison, and it would not be surprising if in pure frustration and despair he just asked his brother to go away. What we do know is that in a letter home Viggo wrote that Rolf 
must never again visit him in prison. The sudden appearance of his brother, immaculately clad in suit and overcoat, might well have disturbed Viggo in his prison clothes and miserable circumstances. Whatever the two brothers may have felt, it would be naïve to think that the German authorities had not somehow and for some reason engineered the visit.

\section{Industry on the Offensive}

Brown Boveri had received the preliminary order for the construction of the $200 \mathrm{MeV}$ betatron, and a new meeting was held in Heidelberg in October 1944 to discuss the plans. The meeting discussed the progress made both by Gund at Siemens and by Rolf at Philips/Brown Boveri.

Siemens had already been working for a long time on the construction of their first betatron. Rolf had a certain amount of contact with the laboratory in Erlangen, and he visited them on several occasions, one of which was in November 1944. They exchanged their experiences of their respective machines, but for several reasons Rolf thought that the Siemens machine would not work very well. He was particularly concerned about the material used to make the vacuum tube, a ceramic material which was a good heat insulator but which he thought was not suitable. He preferred to use a boron-silicate glass that was more resistant to damage from heat. They also discussed the question of frequency, where Rolf thought that he had managed to convince Gund that they were using much too high a frequency. ${ }^{34}$ Rolf later admitted reluctantly that Gund had in fact already got such a machine to work in April. Pedro Waloschek thought that Rolf was always critical of Gund and was unfair to him on this point. ${ }^{35}$

But why were the German authorities so enthusiastic about building betatrons, and in several different places? One theory could be that Nazi Germany was playing the industrial interests of Siemens and Brown Boveri off against each other. They may have been so desperate that they backed both in order to see who delivered the goods first. They can hardly have wanted to build the machine for purely medical reasons. One of the many confusing bits of the puzzle is why Rolf visited Siemens to see the betatron Konrad Gund was working on. Why would he help Siemens by guiding them and setting them on the right track? Was he just genuinely interested and keen to help? We just don't know.

At the Müller factory, work on Rolf's betatron was going ahead at full speed. On one occasion they were visited by Professor Gentner from Heidelberg and the man who had put a stop to the death-ray project, Dr. 
Kulenkampff, who praised the results. By autumn 1944 work on the machine had progressed far enough for Rolf to leave the rest to Kollath and Schumann, with Kollath as scientific leader. Schumann's role was always more diffuse, possibly more political, but both were very able physicists. They dealt with the remaining calibrations and eventually published several papers, including a comprehensive report in Zeitschrift für Naturforschung.

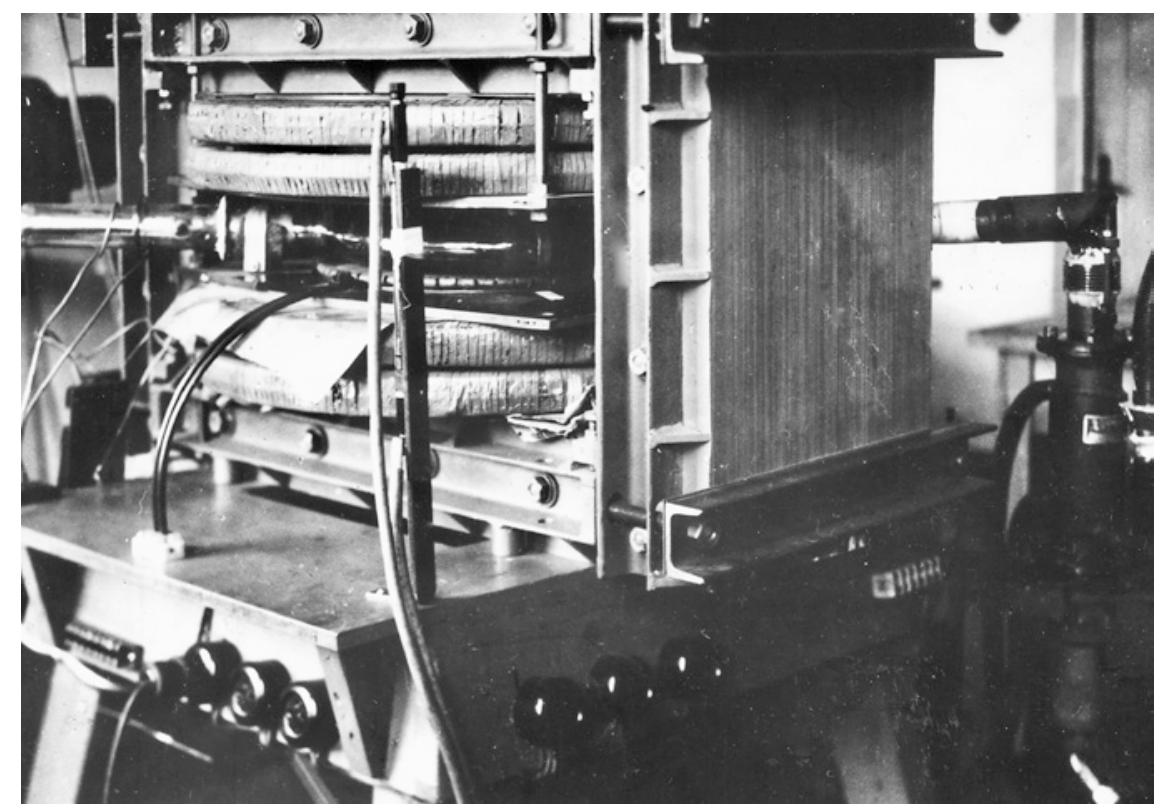

During his stay in Germany during the war, Rolf Widerøe built his first betatron, a $15 \mathrm{MeV}$ machine that the Allies later took as war booty. (Courtesy Smithsonian Institute, Washington DC)

When Rolf told about this in his biography at the age of 90, he added that he had now finished the job and could go home. In the interview with the physicists he said that 'I got permission to go home.' The date for his departure was set for January, and we can sense in his words an awareness that the war was drawing towards a close:

(...) in the course of that autumn the apparatus had come so far that one could say that it was ready for use. But at the same time the English were coming nearer and nearer to Hamburg, and this was well into the start of January 1945 , so I got permission to return home, my job was done, and Kollath took over $(\ldots) .^{36}$ 
It is difficult to say whether he had already planned to go home then. Another question is whether he had been given permission. The noose around Germany was tightening, and there was a question of how long it would be safe to keep Rolf's betatron in Hamburg.

\section{Hollnack Recruits a Courier}

In December yet another name appears in the list of people implicated in the authorities' handling of the Widerøe project. Rolf's administrative superior, Theodor Hollnack, came in contact with an apparently beautiful young man going by the name of Jan Gerrit Overbeek. They first met in a hospital in Marburg, and Hollnack appointed him as his personal courier. The story of how he was recruited to the job sounds like something from a spy novel with undertones of homosexuality. ${ }^{37}$

A 17 year old Dutch sailor in hospital in Marburg said that he had signed on a cargo ship in Duisburg but that he didn't want to go back there. A man came to chat with him and found out that he liked to read. The man offered to give him a book by Nietzche, which he brought the next day. The book was Nietzche's 'Thus Spoke Zarathustra.' He wished the boy a good recovery, handed over the book and left. Inside the book was a handwritten note saying that the boy should report as soon as he was discharged from the hospital and he would see what he could do for him. The note was signed 'Theodor Hollnack, Barracke Mittelfeld, Dillenburg/Dill.' This was a department of the air ministry. The piece of paper was headed: Der Treubänder des Metallurgischen Forschungsinstitutes des Reichsluftfahrtministeriums ('Trusted member of the air ministry metallurgical research department').

On his discharge a few days later, the lad took a bus to the specified address. Hollnack was not there himself, but he had left instructions. Overnight accommodation had also been arranged. The young man should hold himself in readiness, and Hollnack would call when he needed him. This was all he had to do, for a salary of 400 reichsmarks per month. His colleagues were friendly and helpful and didn't know what sort of tasks Hollnack had recruited him to carry out. The former sailor knew nothing about the business either, and Hollnack forbade him to take up personal relationships either within or outwith the office-especially with young women. 
The sailor travelled around a lot with his boss, who drove round in an Opel Kapitän, and on these trips they talked a lot together. He learned that Hollnack was from a Prussian officer's family, that he had previously been a flying instructor and that his immediate superior was Field Marshall Milch, who at the end of 1944 still had a certain amount of power. Seaman Overbeek is the same person as the author Jakov Lind, who many years later in his autobiography described the man who recruited him thus: 'He had short hair and a not unsympathetic face. Brown eyes and a rather short, squashed or high-arched nose.' He also wrote that he thought Hollnack looked like a senior official with his dark blue suit, white shirt and dark tie. ${ }^{38}$ In the book Lind, alias seaman Overbeek, not only changed his own name but also changed 'Hollnack' to 'Kolberg.'

Pedro Waloschek has said that he was in contact with Lind later, and that Lind had confirmed both in letters and in telephone conversations that the person he described was Rolf's superior and his link to the authorities. And the 17 year old in the hospital, who later became a well-known writer in England, was not really Overbeek but the Jew Heintz Landwith, born in Vienna and sent by his parents on a kindertransport to the Netherlands as an 11 year old before they emigrated to Israel. In Netherland he had acquired false papers under the name of Jan Gerrit Overbeek, and after the war he changed his name again, to Jakov Lind.

At about the same time, in November or December, another young man was arrested by the Gestapo. This was Rolf's assistant, the physics student Touschek. He was accused of having been a frequent visitor to a library at Hamburg Chamber of Commerce where he had been observed reading foreign newspapers and magazines. He had also behaved recklessly and provocatively, for example by turning pictures of Hitler upside-down so that the Führer was standing on his head. The Gestapo discovered this and also found out that he was half Jewish. So he was arrested and imprisoned in Fuhlsbüttel, not far from the site of the Müller factory, the same prison where Rolf's brother had been when he was first brought to Germany.

\section{Siemens Joins the Race}

The international research competition was speeding up. While Rolf was proof-reading his article for Archiv für Elektrotechnik early in 1943, the physicist Max Steenbeck had announced the results of his attempt to construct 
a $1.8 \mathrm{MeV}$ betatron in an apparently secret Siemens project. He claimed that he had been able to accelerate electrons to this level ever since the mid 1930s. He explained how he had thought this out, and said that he had applied for several patents. Steenbeck's findings were printed in the journal Naturwissenschaften, and Rolf extended his article to include a commentary on this. He also referred to the fact that Steenbeck had largely mapped out the way to get electrons to follow a stable track.

Steenbeck knew of Rolf's doctoral thesis from 1927 and had used material from it. Rolf had at that time thought about patenting this discovery, but he was busy with other things, not least the relays he was developing, and so he hadn't got round to registering a patent. Steenbeck had faced some of the same problems as Rolf in stabilising the course of the electrons. Rolf had not said anything in his thesis about the conditions for stabilising the electrons, but already in his time as a student he had laid out in his notebook a practicable theory about this, which he rather surprisingly did not subsequently make use of himself.

Siemens regarded the betatron as a German invention which Steenbeck and his boss (who was of Jewish origin) had patented for them in 1933. Siemens had made it possible for Steenbeck's colleague to leave Germany on a commission for them, and Steenbeck had then continued the work alone. ${ }^{39}$ Many people thought that Steenbeck should be recognised as the inventor of the 'stabilising condition' because he achieved it in practice before Kerst, even though with a much smaller machine.

In research, however, every step is built on top of another. Even Steenbeck was not the first. The Englishman T.S. Walton had come across the same formulation from a slightly different direction, and we can therefore say that he was the real inventor of the stabilising condition. That happened in 1929, two years after Rolf's doctorate. But Steenbeck's theories were easier to understand, and his name still appears in the history books as the discoverer. Steenbeck had also been early in the field with similar thoughts to the American, Lawrence, and had worked on a 'synchro-cyclotron.' He wrote a paper about this for the journal Naturwissenschaften but it was apparently never published, allegedly because of a misunderstanding.

Siemens' wartime interest in Steenbeck's patents was primarily in what manufacturing licences might stem from them later. Steenbeck landed a rather modest commission in the first phase, for a small research model that he had to promise to keep strictly secret. 


\section{War on All Fronts}

Because of the armaments race, even Steenbeck had to adjust to accepting military research objectives for his work. At the start of the war his work on the betatron was cancelled by the company management. The following year, Kerst completed his first betatron with the support of General Electric and on 13th November 1944 he submitted a patent application in the USA that was remarkably like the application Steenbeck had submitted in Germany. In Europe, however, Kerst's invention went practically unnoticed.

So General Electric ought to have asked Siemens for permission to use Steenbeck's patent that was based on the designs that Gund had used at Siemens. Steenbeck gave a different version of this. He claimed that the licence was given to Westinghouse in 1941 and that Kerst knew about the patent before he had reached his goal. But the licence didn't count for anything, because all German patents were confiscated immediately after the war. By the time they were given back and current rights could legitimately be used, most of them had already expired. ${ }^{40}$

Rolf has said that he was present during the rights negotiations in Mannheim and Karlsruhe in 1954 when Brown Boveri was required to pay Siemens about 100,000 DM for use of the patents. ${ }^{41}$ Before the end of the war Siemens had registered a series of patents that were considered very interesting. An American report summarising the situation in Europe in the accelerator field shortly after the war lists a total of 14 important technical ideas that had been patented. ${ }^{42}$

Pedro Waloschek, who has studied both Siemens' and Brown Boveri's work on betatrons during the Second World War, thinks that the two companies did have different aims, even though both were supported by the Luftwaffe and both were allocated resources labelled 'for important war research.' He also thinks that the Siemens betatron was originally more directed towards medical use than Rolf's:

Gund's accelerator was designed for a completely different purpose from Rolf's betatron. Possibly under the influence of Schiebold, Seifert and Hollnack, Rolf 
constructed his apparatus mainly for the production of what are called 'hard' $\mathrm{X}$-rays as used mostly for materials testing and possible military applications and less for medical purposes. Gund, on the other hand, responded fully to the medical requirements that Siemens had set. Medical researchers hoped to use suitably fast electrons to reach into deep-lying tumours while causing less damage to the overlying tissue. ${ }^{43}$

Waloschek believes there is evidence that Gund's little betatron was not only the first working German betatron but also the first to be used for scientific work. He claims that the original objective, to draw electrons out of the machine, was attained in 1947 and that the machine seemed remarkably stable and reliable. Irrespective of the original reason for developing betatrons, the later results would depend on the situation. And whatever use was intended, the overall commercial objective for both companies was to make money.

Interest in Siemens' projects spread. Another physicist, Wolfgang Paul who later got the Nobel Prize, had also become aware of the possible uses of betatrons from reading about Kerst's machine and understood clearly that it was a hopeful development towards the German air weapon. ${ }^{44}$ Along with his co-worker who was a professor of nuclear physics and a member of the Uranium Club, ${ }^{45}$ he intended to bring about great things:

We planned that as soon as the war was over or the political situation was suitable we would build such an accelerator. When we then heard that at Siemens they were currently building an accelerator for medical use, we offered our help with the testing. I then taught myself the necessary electronics and nuclear physics, built up the apparatus for this in Göttingen and did the first measurements in Erlangen in summer 1944. 


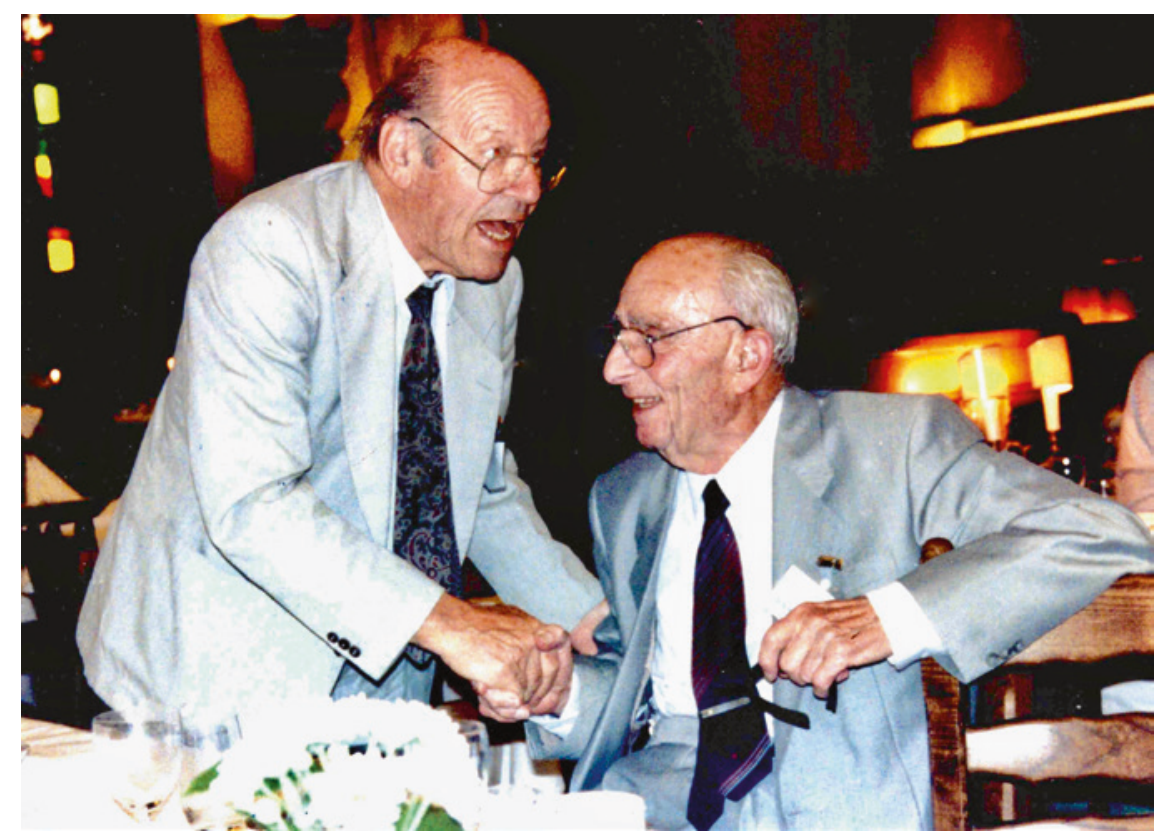

Wolfgang Paul and Rolf Widerøe at an accelerator conference in Hamburg 1992. Professor Paul shared a Nobel Prize in Physics in 1989. (Photo Pedro Waloschek)

So finally it was nevertheless the Steenbeck/Gund project that was the big thing for Siemens and that also drew in other expertise in the field.

\section{Medical Use}

It is difficult to know when Rolf began to think of medical use for betatrons; whether it was before, during or after his stay in Germany during the war. We must remember that what he says about this does not always correspond with reality. One of the people Rolf met at the Brookhaven Institute after the war in connection with the setting up of CERN wrote in an article on the history of accelerators that Rolf had made a convincing impression. He 'spent the war years in Berlin' where he had worked on betatrons. 'The Germans supported this work because Widerøe had convinced them that it would be useful for generating death-rays. ${ }^{46}$

It is difficult to decide from this whether Rolf himself believed his invention could be used as a weapon, or whether this was just something he had let the Germans believe in order to get support for his project. One of the points of detail in this article is that Rolf was said to have lived in 
Berlin during the war, and this has also been claimed by others. Based on impressions from the biography and elsewhere and from conversations with Waloschek, it seems that he lived in Hamburg but that he travelled around a lot. Berlin was the capital city and the centre of Nazi power, and we should perhaps not lay too much credence on an American's statement 30 years later that Rolf lived in Berlin during the war.

Wondering what Rolf thought about the practical application of his work on the betatron, we can see possible scenarios: he believed it could be the basis for further scientific research in physics; he believed it could lead to an important weapon for the air force; or he believed it could be used in medical treatment. But what he said about this outwardly during the waror for that matter afterwards-does not necessarily correspond with what he thought inwardly. In the biography almost 50 years later he is equivocal about this. He says he realises that the reason the Luftwaffe were interested was because a betatron could be used to achieve very high energy X-rays. That gave the supporters of the death-ray project renewed hope, and so they agreed to finance it. 'I wasn't supposed to know anything about this, and we always spoke only about the medical applications.' In a later book, Waloschek writes as follows, with Rolf as the source of his information:

But I consider it more likely that Gerlach had such authority at that time that the political and military officials - including Speer, Milch, Georgii and Geist followed his opinions and decisions without serious question. Gerlach did have full authority over the allocation of research resources to nuclear physics. ${ }^{47}$

\section{The Betatron Must Be Moved to Safety}

The war was still going on, now in its final year. Christmas was approaching, but Hamburg was being subjected to regular bombing raids by the British and Americans. There had been heavy raids every month since the end of June. Germany's biggest seaport was an important target for Allied bombers, with its oil refineries and heavy industry. Blohm \& Voss, for example, built warships and military planes. The Müller factory and surrounding industrial sites were also hard hit. The cellar with the betatron was still intact, but the air ministry ordered the completed $15 \mathrm{MeV}$ machine to be moved to a 'safe place' outside the city. We don't know whether the order really came from the highest level—Milch had gone by now_or whether it came from Colonel Geist or was initiated by Hollnack or Seifert.

With help from Richard Seifert, Kollath and Schumann had the machine dismantled in a couple of months and transported to safety in the remote 
little village of Wrist $60 \mathrm{~km}$. north of Hamburg, near Kellinghusen in the area between Hamburg and Kiel. There, the betatron could be rebuilt without raising suspicion, in a building that was part of a dairy belonging to Seifert's family.

In order for the journey to appear routine, Richard Seifert's youngest daughter Elizabeth was with them in the vehicle. She recalled the dramatic journey later. ${ }^{48}$ Rolf's second-in-command, Kollath, sat on the back seat with Hollnack, with herself on the front seat next to the driver. They were driving without lights, the roads were narrow, there were constant air raids and it was difficult to make progress. Every so often she had to get out to read the road signs, which were partly covered so that they could not be seen from Allied planes. They managed to manoeuvre the apparatus into a building with a big enough door to accommodate it. Only a few people were in the know about this. Probably also among these was Hollnack's courier, who was already in Wrist. When one day he came across a strange machine well camouflaged, he realised that it must be the top-secret betatron.

Here in Wrist they installed the machine, set it running and got it to work just as it had in the laboratory in the Müller factory. Touschek, the student, was in prison and not available to help, but some of the staff from the Müller factory helped to get the machine started and after a while Rolf's team was able to continue the testing and calibration. Subsequent events indicate that Hollnack knew more than most about the Allies' movements, and it was hardly by accident that he acted to get the machine out of Hamburg when he did. It is difficult to assess how much the others were allowed to know—or how much they worked out themselves.

By the beginning of January the courier had been supplied with papers from Hollnack saying that all police and SS personnel were requested to 'be helpful in every way possible' to the courier, who 'was travelling on a mission for the air ministry.' So the assistant spy, as he later described himself, could travel around freely. He carried maps and packages between Hamburg, Berlin, Mannheim, Dillenburg and Dresden, and sometimes to other towns. He spent a lot of time on trains, always travelling first class, and lodged in luxury suites in hotels.

Throughout the winter, Rolf had less and less to do with the $15 \mathrm{MeV}$ betatron. He had been concentrating on the $200 \mathrm{MeV}$ machine that was being built in Mannheim as Ostgrossheim was no longer in use. The patent applications also took up a lot of time. He still dealt with his patent adviser friend in Berlin, and it would be surprising if Rolf did not also use the services of Hollnack's courier, the lad whom Rolf later 'could no longer remember ${ }^{49}$.' In the midst of the dramatic events of war and the industrial conflict, 
Rolf had his own agenda, his own contest between himself and his competitors. He applied for another two patents on 17th and 19th February 1945. He was obviously busy. However little or much he was concerned about the political manoeuvres round about him, he cannot have failed to realise that the war was drawing to a close and that from his point of view this would at the very least create uncertainty about the future of his project.

\section{Driven by Events}

In March, or possibly very early in April, the unexpected happened. Hollnack, who was in charge of finance, gave Rolf a sum of money and told him to go home. Now, and permanently. The payment was large, about 38,000 Reichsmarks, equivalent to about 150,000 Norwegian kroner at that time. Another source says that the payment was 38,000 Norwegian kroner. Whatever the exact amount, he found himself in possession of a small fortune. So we are talking about a payment of a little over 3 million kroneralternatively a little over 800,000 kroner-in 2017 values.

According to Rolf, the special payment was 'for his services.' He later explained that it was payment for the rights to use his patents. ${ }^{50}$ With this money, Rolf disappeared unobtrusively from Hamburg. By train. There were several stops 'because of sabotage to the track' and a stay in Copenhagen 'to put papers in order' at the consulate. He doesn't say anything about what sort of papers, but he had also stopped there on his way home for Christmas the first year, even though on that occasion he was travelling by air. We may well wonder why. He arrived in Oslo, which was still occupied and where he was still employed in Brown Boveri's daughter company NEBB. His time in Germany during the Second World War was over.

He had little idea how he would be received. Why did he take the train, when he always flew? There is no clear explanation for that. The Luftwaffe had arranged flights for him before. Did they not know that he was leaving? Obviously not many people knew. We could say that he was being smuggled out. What currency was he paid in? It would surely not be a good idea to go into a Norwegian bank and ask to pay in a bundle of German marks.

When did he really come home? Different dates are quoted. What had he been doing in February and March? Where had he been? In one place he writes that he was ready to return home in autumn 1944. Elsewhere, he writes that he moved in January or February. Does 'ready to go' mean the same as 'went?' In yet another place he stated that he left in March, but it can have been even later. Letters exist with his signature, dated Hamburg 
12th February 1945. Can the simple explanation be that he spent a long time on the journey home for very practical reasons? It was still wartime. Or was he seeing somebody or doing something on the way, for example in Denmark?

What is certain is that Rolf managed to bring home with him documentation about the work he had been doing in Germany. During his approximately 20 months there, he had accumulated not only a number of patents but also much material that was still incomplete and required further work. Many of his theories and results were still in his head or on rough notes and had not been written up. There would be time for that later.

In Germany, the situation was becoming more and more chaotic. On 14th April American troops freed the Siemens researcher Richard Gans and took over his and Schmellenmeier's betatron laboratory that had been moved to Burggrub. What remained there was probably just ruined and destroyed. ${ }^{51}$ All Nazi Germany's effort to create a radiation wonder-weapon came to a stop. The war was in its end phase, and events now moved quickly:

24th April: Berlin surrounded by Soviet troops

30th April: Hitler commits suicide in his command bunker

3rd May: British troops occupy Hamburg without resistance

7th May: Germany surrenders unconditionally.

\section{The Unveiling}

When the news of Hitler's suicide reached Hamburg, Hollnack's courier revealed his real identity to his boss, namely that he was Jewish and from Vienna, and not the Dutchman he had presented himself as. Hollnack took the news very calmly. He just said 'Ah' and after a little pause said that his secretary, Miss Bluhme, was half Jewish. Now it was the courier's turn to say 'Ah,' though he didn't fully grasp the significance of this revelation and Hollnack had to say plainly: 'I have done important work for the Allies. ${ }^{52}$

The courier was still confused. He couldn't imagine it. He had understood something about the bits of metal in what he called the cyclotron, the grey monster that he said he had seen. He asked Hollnack what he really meant and was told: 'Wait here till the English arrive, then you will see. They are coming today or tomorrow. You have helped me to help the Allies. You will understand the value of this.' He then offered to give the young man a grant so that he could study in England or America. The ex-sailor had turned 18 
and was still without higher education, but he turned down the offer. $\mathrm{He}$ remained in Kellinghusen several more days. The thought of serving as an exemplary Jew with Kollath's Jewish wife and half-Jewish Touschek and Miss Bluhme did not really appeal to him. He would go back to Amsterdam and his friends there. ${ }^{53}$

Theodor Hollnack, who was trusted not only by the Luftwaffe but also by the British, immediately made contact with an English special unit and the manager of the Müller factory. He showed films from the laboratories and workshops where the betatron was developed. All the remaining documents were seized and taken away. Any further activity in the factory was banned. Naturally, the staff were not particularly pleased about this. They knew that both their own company and Philips the mother company considered the development of the betatron very prestigious. They had devoted a lot of work to the project and didn't understand why it could not continue.

Pulling the strings as he always did, Hollnack saw to it that the British allowed the work in the dairy at Wrist to go ahead. That had very probably been arranged already even before the British arrived. At any rate, the team headed by Kollath, Schumann and Touschek could continue the work of calibrating the betatron. ${ }^{54}$

\section{Quite Different Problems}

In Norway, quite different problems awaited Rolf. A few weeks after he came home he was arrested and taken to Ilebu prison camp, the former Grini national prison where the Germans had held Norwegians prisoner and which when freedom came was converted to a prison for people convicted of treason. That was where his brother Viggo had been sent by the Gestapo on 21 st July 1941. That was where the man who would later become Rolf's brother-in-law, Egil Reksten, had been taken on 7th July 1943. Now it was Rolf's turn, but on the other side and for a grotesque accusation of having taken part in the development of the V2 rockets.

As he was allowed to take his papers and notes to the prison, he used his free time to write up reports of his scientific work over the previous two years. In his biography he even manages to say-in a typical Widerøe waythat basically it was good that he was imprisoned, as it gave him plenty time for writing. ${ }^{55} \mathrm{He}$ also sent his wife a long letter with his thoughts for the future. He was no longer receiving a salary, and he was obviously concerned for the family. So he asked Ragnhild to contact the director of NEBB and seek his advice. 
Things now happened fast. In June he was formally dismissed from NEBB, who were concerned about their reputation. They had to earn money, and could not carry the reputational risk of employing someone who was tainted-especially as a manager. Certainly not someone who was under such suspicion. By having him transferred to Switzerland they both rid themselves of a delicate problem and set up arrangements for Rolf's future.

Rolf immediately set about making plans. On Monday 9th July he was released from prison, two days before his 43rd birthday and after being in detention for 47 days. In his own words: 'Then in the beginning of July when I had completed my report, I was released.' That is one way of putting it. He says nothing about his experiences at Ilebu, but he does tell us about the work he has done there.

A recently published book about the troubled times of the treason trials devotes 23 pages to describing harassment, threats and accusations of violent handling at Ilebu, especially during the first weeks after liberation when the prisoners were still being guarded by people from the Home Front. Six men in a one-man cell, eight in a two-man cell, healthy and sick mixed together; people with tuberculosis, venereal diseases, cases of diphtheria, lice, bedbugs, poor food and not much of it, punishment exercises sometimes with the additional humiliation of crawling through muck, random nocturnal rollcalls where the prisoners were commanded to stand out for several hours wearing only their night-clothes. The author writes that the most serious punitive roll-call took place on 8th June 1945, which was while Rolf was there:

The whole prison population at Ilebu was commanded to stand in a punitive roll-call assembly from half past nine in the morning until half past five in the afternoon because a couple of prisoners had managed to escape. ${ }^{56}$

With what is described here and elsewhere about the conditions, it is difficult to imagine that it would be possible to write up research results while a prisoner in Ilebu. More than that, to carry on a dialogue about a job with an international company overseas appears completely impossible, even for a Widerøe. We may wonder whether he had someone working for him behind the scenes. But that was how he presented the story himself.

Whatever the circumstances may have been in the course of his time in prison, he further developed his theory of how to make a new type of accelerator, the synchrotron. By doing this, he was well on the way towards being ready to submit what would be his next patent application. His thoughts 
were concentrated on his work rather than his immediate circumstances. This might have been an extremely goal-orientated and rational person's survival strategy. Don't just think positively, but also carry on with the business. In his defence, if any is needed, it must be said that his feet were firmly on the ground in his concern that his wife and children needed money to live and that he must therefore have a job to go to. The clear-headed, rational thinking of an engineer. He is unemployed and without an income. The solution is the job overseas, which has been in the back of his head as Plan B for a long time.

But even though he had been released from detention, he still did not have permission to leave the country. Nor did he know when his case would come up for trial. Seen from this point of view, writing up his latest research results was the most useful way he could spend his time in prison. It was not in his nature to feel sorry for himself, and it wouldn't help either himself or his family. What mattered was looking to the future.

\section{The World Goes on}

The research race didn't wait for treason accusations to be sorted out. Science has its own arenas. The cyclotron, synchrotron and betatron competitions continued after Hitler's fall, and on both sides of the fronts. First round was the struggle to get hold of the opponent's equipment. The Allies wanted the betatron as war booty, together with all the technical records. Then it was a question of recruiting the enemy's scientists. Those who had not already gone there were brought to the USA, England and the Soviet Union. Industry was on the rise. Brown Boveri, Siemens, General Electric, AEG, Westinghouse, Allis-Chalmers and others in the accelerator field needed to recruit good brains. The world was to be rebuilt. The betatron needed to be taken up and carried forward. The question was who would succeed in this. The race speeded up.

6th August 1945: The atom bomb falls on Hiroshima.

5th September 1945: An American researcher presents his synchrotron theory. Independently and almost at the same time, a Russian presents a similar theory.

11th December 1945: Rolf's former second-in-command writes a four page internal report for the British about the continuing testing of the betatron in Wrist that was still being improved. 
22nd January 1946: Rolf is still in contact with the director of NEBB, even though he is no longer employed by the company. He writes to the director to say that he is working on an apparatus he has provisionally called a 'megatron,' that can generate electrons with a voltage that will 'blow the radiation transformer out of the sky.' It weighs 'only' 150 tonnes, while the massive cyclotron that the Americans are working on weighs 30 times more. ${ }^{57}$

31st January 1946: Rolf visits Tandberg's Patent Office to register a Norwegian patent in which the synchrotron theory is described in detail. This time it is a private patent. He has heard rumours of what is happening in the USA and has done what he can to be well prepared.

August 1946: The researchers at Woolwich Arsenal Research Laboratory in London succeed in converting a betatron into a synchrotron. ${ }^{58}$ This experiment confirms the theory proposed the previous year by the American McMillan and the Russian Veksler. The betatron they use is one that Kerst has built using Rolf's theory. Rolf's Hamburg betatron is sent here to the English laboratory for use in further accelerator research. Thereby, two historic betatrons are now gathered in the same place. ${ }^{59}$

\section{No Passport and Little Money}

Professionally, the past two or three years from 1943 onwards had been a productive phase in Rolf's life, despite the world war and problems on a personal level. His rivals might say that it was excessively productive. He had registered important patents and had brought home preliminary ideas about a synchrotron, a type of accelerator that for some applications was even better than a betatron. He ardently wanted to carry on. For his family, however, the first year of peace was difficult to cope with. Rolf, the breadwinner, had been dismissed from his job, had had his passport confiscated and was facing an indictment.

My wife remembers the second half of 1945 and especially the winter of $1945 / 46$ very well. We had very little money, it was extremely cold and I was in Oslo, unemployed and without a passport. I used this time to sort out and write down my thoughts on what later came to be called a synchrotron. ${ }^{60}$

The case against him in the court dealing with accusations of treason had not yet been decided. But nobody could take away his enterprising spirit. His perseverance would be rewarded. He managed to acquire a temporary passport, valid for one month, and permission to travel to Zurich. By Easter 1946 he was in Switzerland negotiating a contract of employment with 
Brown Boveri. He was to develop new and better betatrons. Officially he was not due to begin until 1st August, but mentally he was already well into the job and on 15th May he applied for his first Swiss patent, which was about the principles for making synchrotrons. In due course, he was issued with a normal passport. He also acquired access to money. The remaining 50 years of his life would be spent mostly outside Norway. That was not how his life was planned, but that was how it would work out. Norway was not interested in attracting him back, and he did not try to come back.

The previous three years had been 'The Dark Chapter:' first a year and a half in Germany up to autumn 1945; then a year and a half in Norway before he moved to Switzerland. He had been in the midst of incredibly dramatic events. Like a bad dream. On all fronts: at home and in his research. Caught between German Nazis and loyal Norwegians. Boxed in among spies and big industry in the atomic power race. In war and peace. Roaming freely and walled in. Exhausting even for a cool-headed engineer. 'If I hadn't experienced it myself I wouldn't have believed it,' as he said looking back when he was 91. That I do believe.

Then one day the nightmare passed. One Saturday afternoon, 18 months after he had been arrested, he left Oslo Police Office on Victoria Terrace as a free man. He walked out onto the street in the pale light of autumn. Relieved, at any rate apparently so. Finished with the war-perhaps. He had signed the necessary papers agreeing to pay a fine in lieu of prosecution. Case assessed; application accepted; fine paid; case against him officially closed-all in accordance with the law. The treason department could now archive case number 3418/45, and he would not have to face any further legal proceedings.

It was half past three on the afternoon of Second November in the Year of Our Lord 1946.

The strange, dark chapter of Rolf's life was over. He left Norway a few days later. Permanently. Acquitted, but stigmatised for ever.

Ragnhild and the children were waiting for him in Switzerland. Also awaiting him was a senior position in one of Europe's leading technology companies.

\section{Notes}

1. The biography.

2. There is some disagreement about whether or not they were in uniform. The biography says that they were uniformed. The case notes from the 
treason trial refer to 'several German gentlemen.' (Document 8, handwritten 'Account of my work in Germany etc.', 24/5-45, National Archives, Treason Case number 3418/45 Clause).

3. H. Watzlawek, 23rd February, 17th March and 15 June. Copies of the letters are in the ETH library in Zurich. The letters contain references to letters from Rolf on 6th February and 1st March.

4. The interview with the physicists.

5. Pedro Waloschek in an e-mail to me on 7th June 2011. He had then had it confirmed from the printed edition of the journal in the library at DESY that another article of the same length had been inserted in the relevant pages. Dr. Giulia Pancheri, Theory Group-Research Division, INFN Frascati National Laboratory, Italy, was also in e-mail communication with Waloschek and me about this and uses the information in an article about Bruno Touschek which at that time had not yet been published.

6. Tor Brustad in an interview during preparation of the book.

7. The interview with the physicists.

8. The interview with the physicists.

9. The biography.

10. The interview with the physicists and the biography.

11. Pedro Waloschek: Todesstrablen. The manager of the factory was Hans Ritz, with Dr. Werner Fehr as second-in-command. The two engineers were Gert Krohn and Friedrich Reiniger. A Mr. Bergmüller is also mentioned.

12. The biography.

13. Pedro Waloschek told me in an interview that he had a conversation with three former Müller employees indicating that was the case. It is however possible that the former employees Waloschek spoke with almost 40 years later had not been interested in this and so had not remembered the details. He said that competition between the major companies played a big part in events, as they prepared themselves for production of betatrons after the war.

14. Waloschek gave the number of patents as 12, in Todesstrablen, p. 110.

15. Schiebold's archived papers at the University of Leipzig.

16. Interview during preparation of the book.

17. Rolf Widerøe explained the 'death ray weapon' thus in the interview with the physicists: 'Schiebold had got the idea that he could build an X-ray tube where the cathode was like a concave mirror. Then the electrons would gather on the anode and he would be able to get an X-ray beam that was partially focussed upward.'

18. The British project is described in the book 'Most Secret War' by the physicist R.V. Jones who worked for the British Intelligence Service during the war.

19. Pedro Walsochek: Todesstrablen.

20. The interview with the physicists. 
21. The biography.

22. Waloschek in conversation with me.

23. Schiebold's son Joachim found the film and passed it on to Pedro Waloschek.

24. Fehr, Bergmüller and Reiniger.

25. The interview with the physicists.

26. According to an interview I had with Pedro Waloschek.

27. Pedro Waloschek in an interview during preparation of the book. Richard Gans was also the teacher in Buenos Aires who was fascinated by betatrons and whom Pedro Waloschek writes about in the introductory chapter of his biography of Rolf.

28. Gerlach's notes of the meeting dated 25th August 1944 and Waloschek's Todesstrablen, p. 129.

29. The biography. Waloschek: Todesstrablen.

30. The biography.

31. Question to Rolf from Finn Aaserud, the interview with the physicists in Oslo 1983.

32. According to Waloschek.

33. The biography.

34. The biography and the interview with the physicists.

35. In conversation during the preparation of the book.

36. The biography.

37. Waloschek: Todesstrahlen.

38. Jacov Lind: Selbsportrat, Picus Verlag, Wien 1997.

39. Reinhold Rüdenberg was a pioneer of high energy radiation whom Rolf had known about while he himself was working at AEG in Berlin long before the war.

40. Kaiser, H. F. (U.S. Naval research Lab., Washington, D.C.): 'European Electron Induction Accelerators', Journal of Applied Physics 18. 1-17 (1947) Per F. Dahl: 'Rolf Widerøe: Progenitor of Particle Accelerators', Superconducting Super Collider Laboratory, Dallas, Texas, March 1992.

41. Waloschek: Todesstrahlen.

42. Kaiser.

43. Waloschek: Todesstrahlen.

44. Wolfgang Paul: http://nobelprize.org/nobel_prizes/physics/laureates/1989/ paul-autobio.html.

45. Hans Kopfermann.

46. John P. Blewett: 'Reminiscences about Accelerators', Brookhaven Lecture, October 15, 1980.

47. Waloschek: Todesstrahlen.

48. In a letter to Pedro Waloschek in 1994. Elisabeth, whose surname is now Samisch, is the third generation in the family company and has for many years been owner and managing director of Rich. Seifert \& Co. The 
company, respected in the field of X-ray technology, was bought by Agfa in 2001 and is now part of the GE Group.

49. Waloschek: Todesstrablen.

50. Waloschek: Todesstrahlen.

51. http://germansecretweaponsnazi.devhub.com/blog/category/exotic/page-3/.

52. Waloschek: Todesstrahlen. Overbeek/Lind's autobiography, p 158.

53. Waloschek: Todesstrahlen.

54. Kollath: Notat 11 December 1945, ETH-Library Zurich Hs 903: 28.

55. The biography. The interview with the physicists.

56. Ingrid Hagen: Oppgjørets time. Om landsvikoppgjørets skyggesider, Spartacus 2009.

57. Letter from Widerøe to Solberg 22 January 1946, ETH-Library Zurich Hs 903: 80 .

58. The physicists D.E. Barnes and Frank Goward converted a $4 \mathrm{MeV}$ betatron to an $8 \mathrm{MeV}$ synchrotron. This was the first experimental proof of Veksler and McMillan's synchrotron principle.

59. E.J.N. Wilson: 'Forty Years of Synchrotrons,' CERN, Geneva.

60. The biography.

Open Access This chapter is licensed under the terms of the Creative Commons Attribution-NonCommercial-NoDerivatives 4.0 International License (http:// creativecommons.org/licenses/by-nc-nd/4.0/), which permits any noncommercial use, sharing, distribution and reproduction in any medium or format, as long as you give appropriate credit to the original author(s) and the source, provide a link to the Creative Commons license and indicate if you modified the licensed material. You do not have permission under this license to share adapted material derived from this chapter or parts of it.

The images or other third party material in this chapter are included in the chapter's Creative Commons license, unless indicated otherwise in a credit line to the material. If material is not included in the chapter's Creative Commons license and your intended use is not permitted by statutory regulation or exceeds the permitted use, you will need to obtain permission directly from the copyright holder.

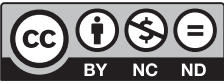

